Hine, A.C., Feary, D.A., and Malone, M.J. (Eds.)

Proceedings of the Ocean Drilling Program, Scientific Results Volume 182

\title{
1. LeG 182 SYNTHESIS: EXPOSED SECRETS OF THE GREAT AUStralian Bight'
}

\author{
David A. Feary, ${ }^{2}$ Albert C. Hine, ${ }^{3}$ Noel P. James, ${ }^{4}$ and \\ Mitchell J. Malone 5
}

\begin{abstract}
During Ocean Drilling Program (ODP) Leg 182, nine sites were drilled across the southern Australian margin in the Great Australian Bight, with the objective of obtaining a more detailed understanding of cool-water carbonate depositional processes and global environmental change in mid-latitude settings. Drilling results provide insights into the temporal and spatial aspects of cool-water carbonate deposition in shelf edge and slope environments. Drilling showed that the spectacular prograding clinoform sequence forming the upper slope and outermost shelf of the Great Australian Bight margin was rapidly deposited during the Pleistocene. Meter-scale lithologic cycles rapidly accumulated in response to orbitally forced sea level fluctuations. Skeletal elements within these wackestone to packstone, coarsening-upward cycles consist of tunicate spicules, brown bioclasts, bryozoan fragments, and red coralline algal debris-a heterozoan assemblage typical of coolwater carbonates. The high accumulation rates, comparable to rates in warm-water carbonate environments, reflect partitioning of sedimentation between the shelf and slope as high wave energy from the Southern Ocean interacted with sea level fluctuations to generate vigorous off-shelf transport.

Mound features visible on seismic reflection data on and underlying the uppermost slope throughout the Pleistocene of the central and western Great Australian Bight are in situ bryozoan reef mounds. These mounds consist of diverse suites of bryozoans, together with coralline algae, echinoid spines, and benthic foraminifers, in a mudstone to
\end{abstract}

${ }^{1}$ Feary, D.A., Hine, A.C., James, N.P., and Malone, M.J., 2004. Leg 182 synthesis: exposed secrets of the Great Australian Bight. In Hine, A.C., Feary, D.A., and Malone, M.J. (Eds.), Proc. ODP, Sci. Results, 182, 1-30 [Online]. Available from World Wide Web: $<$ http://www-odp.tamu.edu/ publications/182_SR/VOLUME/ SYNTH/SYNTH.PDF $>$. [Cited YYYYMM-DD]

${ }^{2}$ Board on Earth Sciences and Resources, National Research Council, Washington DC 20001, USA. dfeary@nas.edu

${ }^{3}$ Department of Marine Science, University of South Florida, 140 7th Avenue South, St. Petersburg FL 33711, USA.

${ }^{4}$ Department of Geological Sciences, Queens University, Kingston ON K7L 3N6, Canada.

Integrated Ocean Drilling Program and Department of Geology and Geophysics, Texas A\&M University, 1000 Discovery Drive, College Station TX 77845-9547, USA.

Initial receipt: 9 April 2003 Acceptance: 12 April 2004

Web publication: 10 June 2004

Ms 182SR-017 
packstone matrix. Seismic and isotopic data indicate that mounds developed cyclically in response to glacial-interglacial productivity cycles. Increased upwelling during sea level lowstands promoted active mound growth, in contrast to the thin mud accumulations that draped inactive mounds during highstands. Such mounds have not previously been described from the "modern" ocean and provide unlithified analogs for similar features that occur in the mid- to late Paleozoic rock record.

The interaction of high-salinity (up to 106\%) interstitial brines with abundant organic matter within the upper parts of the sedimentary succession produced high concentrations of methane (up to 50\%) and hydrogen sulfide (up to 15\%). This unusual chemical environment lead to extensive carbonate recrystallization and dissolution of highmagnesium calcite and the precipitation of low-magnesium calcite and dolomite. In certain environments, therefore, cool-water carbonates may be at least as diagenetically active as their warm-water counterparts. The brines probably formed in shallow evaporative pools and lagoons on the shelf during sea level lowstands, seeped into the underlying sediments, and flowed toward the upper slope. Thermodynamic considerations suggest that $\mathrm{H}_{2} \mathrm{~S}$ and $\mathrm{CH}_{4}$ disseminated gas hydrates might be present within the Great Australian Bight succession.

\section{INTRODUCTION}

The cool-water temperate carbonate depositional realm is neither as well documented nor as well understood as the more familiar warmwater tropical domain (Nelson, 1988; James, 1997). This is largely because these sediments, formed and deposited in waters $<20^{\circ} \mathrm{C}$, occur in inhospitable environments that are difficult to study. Apart from southern Australia, New Zealand, and the peri-Mediterranean region, the Cenozoic record of these deposits is meager and most are buried in the subsurface. Leg 182 sites provided the opportunity for new insights into the spatial and temporal aspects of temperate carbonate deposition in shelf edge and upper slope environments.

Nine sites were drilled during Leg 182 in the western Great Australian Bight (GAB) (Fig. F1), extending from the shelf edge (203 $\mathrm{m}$ water depth) to the middle continental rise (3874 m water depth) (Hine et al., 1999; Feary, Hine, Malone, et al., 2000). The shallower sites were distributed between two shelf edge to upper slope transects, forming eastern (Sites 1127, 1129, and 1131) and western (Sites 1130 and 1132) transects (Fig. F1). The primary drilling objective for the leg was a more detailed understanding of global environmental change in high- to mid-latitude settings. Within this broad overall objective were a number of primary aims:

1. To understand the detailed anatomy of a Cenozoic cool-water carbonate margin by recovering cores from different facies deposited in various water depths during a range of geologic periods;

2. To test and refine the global sea level curve and, most importantly, describe the reaction of cool-water carbonate depositional systems to different phases of the sea level cycle (the intention was to compare the response to sea level fluctuations of this cool-water carbonate depositional system to records from warm-water, rimmed, and unrimmed carbonate platforms);
F1. Leg 182 drill sites, p. 19.

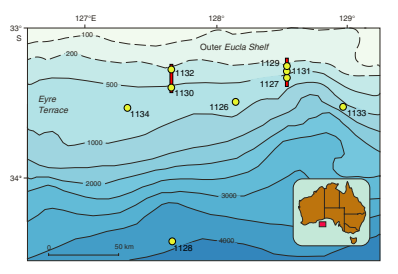


D.A. FeARY ET AL.

3. To use biological and chemical paleoenvironmental proxies to decipher a detailed paleoceanographic record to more precisely describe the timing and paleoceanographic effects of the opening of the Tasman Gateway and the influence of the Leeuwin Current on paleoproductivity over time; and

4. To provide high-resolution data on the tempo and pattern of biotic evolution in oceanic and neritic environments.

In addition, there were two secondary objectives:

1. To understand the hydrology of a carbonate platform adjacent to a vast inland karst with sluggish water circulation and

2. To determine the nature of early burial diagenesis (lithification and dolomitization) in a cold, seawater-dominated system.

The southern Australian continental margin has been the site of coolwater carbonate sedimentation since Eocene time, resulting in an almost 1-km-thick carbonate succession (Fig. F2), and it is now the largest area on the globe composed of such sediments. There has been negligible terrigenous sediment input into the region since the late Eocene, as no major rivers enter the shelf across the width of the Great Australian Bight. In addition, this location offered the potential to collect high-resolution stable isotope and biostratigraphic profiles to clarify several important stages in the evolution of the Southern Ocean.

The longevity of the carbonate depositional system is in part a consequence of the tectonic stability of this sector of the southern Australian margin throughout the Cenozoic, particularly since the Miocene. The region has a relatively simple tectonic history as a divergent, passive continental margin that formed during the protracted period of extension and rifting that led to the separation of Australia and Antarctica in the Cretaceous and evolved during the subsequent northward drift of the Australian continent. The initial extension phase prior to breakup in the mid-Cretaceous (96 Ma), together with the following period of slow spreading (until the middle Eocene-49 Ma), resulted in deep continental margin basins filled with as much as $12 \mathrm{~km}$ of mainly terrigenous clastic sediment (Willcox et al., 1988; Davies et al., 1989). These basins broadly correspond to the sites of modern upper-slope terraces (e.g., the Eyre Terrace at 400-1600 m water depth in the western Great Australian Bight) (Fig. F1). The onset of faster spreading in the middle Eocene also corresponded to establishment of fully marine conditions and initiation of carbonate sedimentation in the widening "gulf" between Australia and Antarctica. Carbonate sedimentation continued throughout the remainder of the Cenozoic, as the gulf evolved first into a broad, open seaway and then into the modern Southern Ocean. Cenozoic sedimentation resulted in an extensive, relatively thin (up to 800 m) Eucla Basin succession (Feary and James, 1998) deposited in a predominantly platform-sag to platform-edge tectonic regime (Stagg et al., 1990). Geohistory analysis indicates that the region had minimal Tertiary subsidence (Hegarty et al., 1988). Slight regional tilting $\left(<1^{\circ}\right)$ in the middle Miocene resulted in uplift and exposure of the Nullarbor Plain and restriction of Neogene sedimentation to the modern outer shelf and upper slope.

This synthesis incorporates information from the Leg 182 Initial Reports volume (Feary, Hine, Malone, et al., 2000), publications by Leg 182 shipboard participants in open literature, and papers and data reports in this Leg 182 Scientific Results volume. We are aware of continuing
F2. Cenozoic sequences, p. 20.

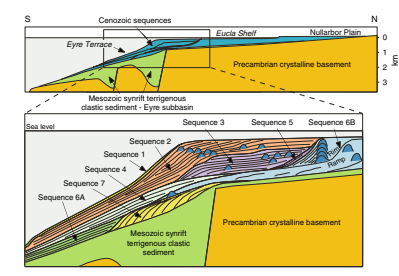


D.A. FEARY ET AL.

work, particularly addressing the "sea level" and "paleoceanography" elements of the leg primary objectives (described above). Accordingly, the components of this synthesis that address these objectives can be considered as interim statements. The primary findings of the leg are presented in the following sections:

1. Apply biostratigraphic and magnetostratigraphic results to revise the regional history of Cenozoic deposition along the Great Australian Bight continental margin;

2. Summarize characteristics of the abnormally thick Pleistocene wedge that underlies the present outermost shelf and uppermost slope;

3. Describe the bryozoan-dominated biogenic mounds (cool-water "reefs") that developed immediately below the shelf edge during much of the Pleistocene;

4. Outline the spectacular and abnormal geochemical conditions that produced extraordinarily high $\mathrm{CH}_{4}$ and $\mathrm{H}_{2} \mathrm{~S}$ contents within the upper part of the Pleistocene succession; and

5. Use the deepwater clay mineralogy record to reconstruct paleoceanographic and paleoclimatic conditions during the EoceneOligocene.

\section{PRIMARY FINDINGS}

\section{Regional Seismic Stratigraphy}

The Eucla Basin extends inland as much as $350 \mathrm{~km}$ from the present coastline and seaward some $200 \mathrm{~km}$ to the modern shelf edge and upper slope. Inland, the Eucla Basin succession thins and "feathers" out against Precambrian basement; it gradually thickens southward and is thickest beneath the modern shelf edge (Fig. F2). Regional seismic stratigraphy shows that the succession is basically divisible into two megasequences, separated by a major basin-wide unconformity: a Mesozoic (?Late Jurassic-Cenomanian) (Stagg et al., 1990) siliciclastic-dominated synrift to early postrift section and a Cenozoic (Paleocene-Holocene), predominantly carbonate dominated section. The extensive erosional unconformity at the top of the synrift section forms an easily recognizable and mappable surface that is overlain by seven unconformitybounded seismic sequences (Fig. F2) (Feary and James, 1998). Apart from the basal siliciclastic sequence both offshore (Sequence 7) and onshore (Hampton Sandstone) and a thin, transgressive, paleovalley-filling and strandline succession of terrigenous clastics on the inland margins of the basin, the Cenozoic succession in the Eucla Basin consists entirely of carbonate-dominated sediment.

Prior to Leg 182, the Cenozoic stratigraphy of the offshore Great Australian Bight succession was based on tentative seismic character correlations and "the division of the ... sequences into a reasonable timestratigraphic framework" (Feary and James, 1998). The stratigraphic results from Leg 182 drilling permit a much more detailed description of the regional stratigraphy (Fig. F3), based on Li, McGowran, and James (this volume), Li, McGowran, and Brunner (this volume), and Li et al. $(2003,2004)$, together with biostratigraphic information from Brunner et al. (this volume), Ladner (this volume), and Sanfilippo and Fourtanier (this volume) and magnetostratigraphic data from Molina Garza and Fuller (2002) and Fuller et al. (2003). Using the original sequence
F3. Leg 182 seismic stratigraphy summary, p. 21.

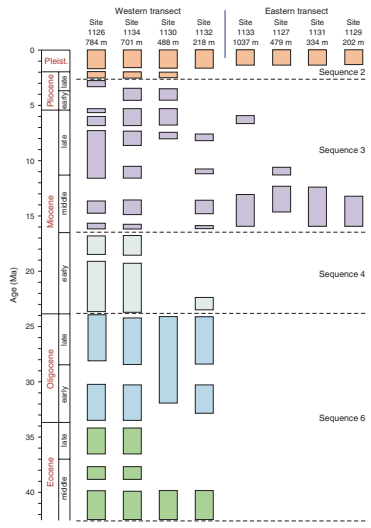


D.A. FeARY ET AL.

designations from Feary and James (1998) to emphasize the updated stratigraphy, these interpretations indicate that the offshore Cenozoic succession represented schematically in Figure F2 consists of the following sequences:

\section{Sequence 7}

Because drilling was unable to penetrate more than a few meters into this wedge-shaped progradational sequence, with negligible recovery, the age of the base of this predominantly siliciclastic sequence remains tentatively estimated as early to middle Eocene. Inconclusive biostratigraphic data indicate that the top of Sequence 7 is probably of middle Eocene age ( 43 Ma).

\section{Sequence 6A}

This multilobed deepwater carbonate sediment apron was deposited from the middle Eocene to late Oligocene. Poor core recovery in this deeper part of the succession precludes any clear indication of the duration of the hiatus at the basal sequence boundary. Biostratigraphic data indicate that Sequence 6A deposition was interrupted by four hiatuses, two of which probably coincide with the disconformable boundaries between the three sediment lobes that compose this sequence.

\section{Sequence 6B}

Seismic images indicate that this sequence consists of cool-water ramp carbonates with biogenic mounds (estimated to be of middle-late Eocene to Oligocene age) that evolved into a warm-water, flat-topped platform rimmed by the ?early-middle Miocene "Little Barrier Reef" of Feary and James (1995). Although only the lowermost, middle Eocene part of this sequence was sampled during Leg 182, the indications from planktonic foraminferal assemblages that subtropical conditions existed in the earliest middle Miocene provides support for the inference that the reef component of this sequence was deposited at this time. A part of the long time period represented by accumulation of Sequence 6B in a proximal shelf setting corresponds to deposition of Sequence 4 in a distal slope setting -inadequate seismic resolution meant that additional sequence boundaries, corresponding to the upper and lower Sequence 4 boundaries, could not be identified within "mega"-Sequence $6 \mathrm{~B}$.

\section{Sequence 5}

This small and areally restricted sediment wedge was not cored during Leg 182. It lies at the foot of the steepest part of the Sequence 6B carbonate shelf escarpment zone, and based on seismic stratigraphic relationships, is estimated to be of earliest middle Miocene age.

\section{Sequence 4}

Although this extensive aggradational deepwater carbonate ramp sequence was expected to be of late Miocene age, biostratigraphic data indicate that the drilled part of this sequence was deposited entirely during the early Miocene. Deposition was interrupted by three short hiatuses. This deepwater ramp sequence is therefore coeval with part of Sequence 6B. 
D.A. FEARY ET AL.

LEG 182 SYNTHESIS: EXPOSED SECRETS OF THE GAB

\section{Sequence 3}

Biostratigraphic data indicate that this aggradational deepwater carbonate ramp sequence, estimated prior to drilling to be of latest Miocene to early Pliocene age, was deposited from the earliest middle Miocene to the late Pliocene. Deposition of Sequence 3 was interrupted by numerous brief hiatuses. The basal hiatus was $<0.5 \mathrm{~m}$.y. in duration.

\section{Sequence 2}

This thick succession of cool-water carbonates with spectacular clinoform ramp geometry that forms most of the modern outer shelf and contains large deepwater biogenic mounds was thought to be of Pliocene-Pleistocene age. Stratigraphic results show that this sequence is almost entirely of Pleistocene age, with only a thin late Pliocene component at the base. Accordingly, Pleistocene sedimentation rates were much higher than anticipated. The hiatus representing the major unconformity at the base of Sequence 2 has a short duration at the deepwater Site 1128 but is of longer duration at shallower sites. At Site 1129, located at the shelf edge, the hiatus has a duration of $>12$ m.y.

\section{Sequence 1}

The extremely thin deepwater drape was confirmed to be of latest Quaternary age.

These revised sequence ages, considered together with their areal distribution (Feary and James, 1998) and paleobathymetric attributes (Feary, Hine, Malone, et al., 2000), provide a complex picture of multiple and shifting depositional loci through much of the early and middle Cenozoic as the slope and shelf evolved, succeeded through the later Cenozoic by a more simple depositional system concentrated at or immediately seaward of the shelf edge. Overlying the regional unconformity at the base of the Cenozoic, the ?early-middle Eocene Sequence 7 was deposited as a prograding siliciclastic wedge seaward of a large crystalline basement high. Carbonate deposition commenced in the middle Eocene as the multiple aggradational sedimentary lobes of Sequence $6 \mathrm{~A}$ were deposited in a deepwater ramp setting (middle to upper bathyal water depths of 200-1000 m) seaward of the Sequence 7 siliciclastic wedge. Sequence 6A lobe deposition continued until the latest Oligocene. The ramp component forming the lower part of Sequence 6B, deposited on the adjacent shelf landward of the siliciclastic wedge, was coeval with Sequence $6 \mathrm{~A}$. The basal portion of the Sequence $6 \mathrm{~B}$ ramp extends landward to correlate with the middle to late Eocene Wilson Bluff Limestone onshore, and the middle part of this sequence correlates with the midOligocene to early Miocene Abrakurrie Limestone. The early Miocene component of Sequence 6B also correlates with the deepwater deposition of the thin aggradational Sequence 4 (middle bathyal water depths of 600-1000 m). The uppermost part of shelfal Sequence 6B, assumed to be of latest early to earliest middle Miocene age and correlated with the Nullarbor Limestone onshore, formed the barrier reef system underlying the present-day mid-shelf (Feary and James, 1995). The reef front was draped with the thin wedge-shaped Sequence 5, probably also in the earliest middle Miocene, as sediment was stripped from the shelf and deposited at the shelf edge as sea level fell. Sequence 3 was deposited in deep water (lower bathyal water depths of 1000-2000 m) seaward of the 
D.A. FEARY ET AL.

reefal system during the extended interval from the middle Miocene until earliest late Pliocene. This aggradational sequence contains numerous hiatal surfaces and was terminated by an erosive event that resulted in a marked erosional unconformity at the top and on the seaward margin of the sequence. Following a diachronous hiatus of as long as $12 \mathrm{~m} . \mathrm{y}$., Sequence 2 was deposited in upper bathyal water depths (200-600 m) as a spectacular sigmoidal unit that forms a thin succession over the outer shelf, reaches peak thickness at the present shelf edge, and thins as a wedge farther seaward beneath the modern slope. Sequence 2 contains the bryozoan mound complexes that developed immediately below the shelf edge (200-300 m water depth) during low sea levels across the central and western Great Australian Bight. The final depositional event was the mantling of deeper-water areas of the margin (below 150-200 m water depth) by Sequence 1 carbonate mud during the last sea level highstand.

\section{Accumulation Rates and Sedimentary Cycles in the Upper Pliocene-Pleistocene Upper Slope Sedimentary Wedge}

One of the most striking discoveries of Leg 182 drilling was the considerable thickness (530 $\mathrm{m}$ at Site 1129) and high sediment accumulation rates of the upper Pliocene-Pleistocene succession that forms the upper slope in the central Great Australian Bight (Feary, Hine, Malone, et al., 2000). In cross section (Fig. F2), the outer shelf-upper slope succession (Sequence 2) is a sigmoid-shaped sedimentary package with spectacular clinoform geometry (Figs. F4, F5) that forms a distally steepened carbonate ramp (cf. Read, 1985). As noted above, the base of Sequence 2 is defined by a pronounced unconformity representing an erosional hiatus where 2- to 12-Ma strata are missing. At its thickest point, this sigmoidal prograding unit is more than twice as thick as the entire underlying succession of upper Miocene to middle upper Eocene cool-water carbonates, emphasizing the significance of the PliocenePleistocene period for cool-water carbonate sedimentation.

Although the presence of several hiatal surfaces within Sequence 2 results in variable sediment accumulation rates (Holbourn et al., 2002), the highest calculated accumulation rate from biostratigraphy (based on nannofossil datums) (Ladner, this volume) is $62.5 \mathrm{~cm} / \mathrm{k} . \mathrm{y}$. at Site 1127 on the eastern drilling transect. This rate compares favorably and even exceeds accumulation rates estimated for warm shallow-water carbonate sedimentary environments (30-100 cm/k.y.) (Schlager, 1981; James and Bone, 1991). It is clear that the vigorous off-shelf transport of carbonate sediments from the shallow-water carbonate factory is of critical importance for the development of this prograding wedge (James et al., 1994).

The western drilling transect, consisting of Sites 1132 and 1130, has a less pronounced clinoform seismic geometry (Fig. F5), and calculated accumulation rates for the Pliocene-Pleistocene succession are substantially lower than those for the eastern transect $(26 \mathrm{~cm} / \mathrm{k} . \mathrm{y}$. at Site 1130 and $8.8 \mathrm{~cm} / \mathrm{k} . \mathrm{y}$. at Site 1132). Seismic data indicate that these lower accumulation rates within Sequence 2 are more typical of the entire Eucla margin and that the eastern transect corresponds to the highest accumulation zone. This indicates that accelerated productivity and/or more vigorous off-shelf transport must have occurred preferentially in the area of the eastern transect compared to the rest of the margin-the
F4. Eastern transect, p. 22.

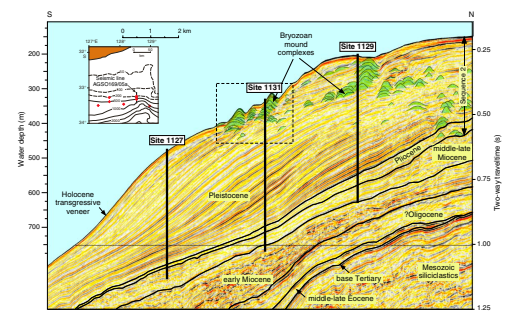

F5. Western transect, p. 23.

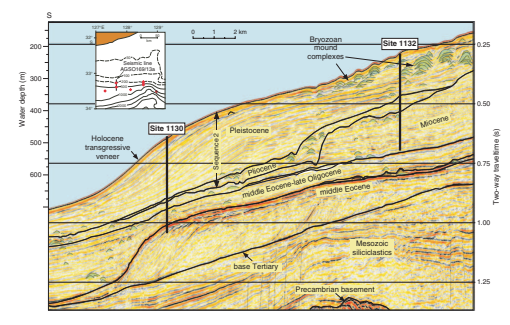


D.A. FEARY ET AL.

reasons for this are still unknown, although focused downwelling may have played a role.

A number of downhole logging parameters (gamma radiation, uranium, resistivity, and Formation MicroScanner data) from the Pleistocene clinoform succession show pronounced cyclicity (Feary, Hine, Malone, et al., 2000), which can be correlated with cycles visible in oxygen isotope curves compiled for parts of this sequence (Holbourn et al., 2002; Andres et al., 2003; Andres and McKenzie, this volume). These curves were compiled from analyses of benthic foraminifers (Holbourn et al., 2002), planktonic foraminifers (Andres et al., 2003), and both bulk and fine-fraction sediment (Andres and McKenzie, this volume). All three signal sources show that the marine isotope stages (MIS) can be recognized when the data are compared using the age models developed for each site and the SPECMAP stack (Imbrie et al., 1984) (e.g., Fig. F6). The GAB oxygen isotope signals have unusually low amplitudes when compared to other oxygen isotope curves based on planktonic foraminifers. This may be due to the contribution from shelf-derived sediment (Andres and McKenzie, this volume) or to only subtle water temperature changes at the seafloor during sea level fluctuations (Holbourn et al., 2002).

Mid-Pleistocene cycles ( $10 \mathrm{~m}$ thick) along the eastern transect are correlated to sea level changes arising from obliquity-scale (41 k.y.) orbital forcing (Saxena and Betzler, 2003). Finer-grained (wackestone) sediment at the base of each cycle grades upward to coarser-grained (packstone) sediment at the top. Analysis of particle constituent trends indicates that tunicate spicules, brown bioclasts, bryozoan fragments, and red coralline algal debris are shed to the slope during sea level rises and sponge spicules and micrite are shed during sea level falls. The brown bioclasts may be the common skeletal intraclasts found on the modern shelf and described by James et al. (2001). This particle constituent partitioning produced pronounced mineralogic cyclicity. Highmagnesium calcite (HMC) and aragonite are a more abundant component of the succession during sea level rises and highstands (Saxena and Betzler, 2003; Andres and McKenzie, this volume; Swart et al., this volume). Siliciclastic input, in the form of clay minerals, is higher during sea level highstands, reflecting higher rainfall and runoff. Dolomite is also present in sediment deposited during sea level rises (Saxena and Betzler, 2003). The presence of dolomite rhombs in the fine fraction on the modern shelf (James et al., 2001) indicates that at least some of the dolomite within the Pleistocene succession may be detrital. The relatively high amount of aragonite (30\%) suggests that cool-water carbonates should not be considered as mostly calcitic (Saxena and Betzler, 2003). This is further supported by the high-resolution mineralogy record presented by Swart et al. (this volume).

In order to understand the timing of off-shelf sediment export during a single sea level cycle, Hine et al. (this volume) obtained 31 accelerator mass spectrometer (AMS) ${ }^{14} \mathrm{C}$ dates from the upper few meters at six different sites. By dating the fine-grained fraction $(<62 \mu \mathrm{m})$ and comparing these data to well-known late Pleistocene to Holocene sea level curves (e.g., Fairbanks, 1989), they determined that the most rapid sediment accumulation rates occurred during the fastest transgressive component of the sea level cycle. At Site 1130, for example, from 19 to $13.95 \mathrm{ka}$, the calculated sediment accumulation rate was $656 \mathrm{~cm} / \mathrm{k} . \mathrm{y}$. This is an order of magnitude faster than the fastest rate derived using biostratigraphic datums (Ladner, this volume), which are calculated over a much longer time frame. This transgressive rate is also an order
F6. Carbon and oxygen isotope events, p. 24.

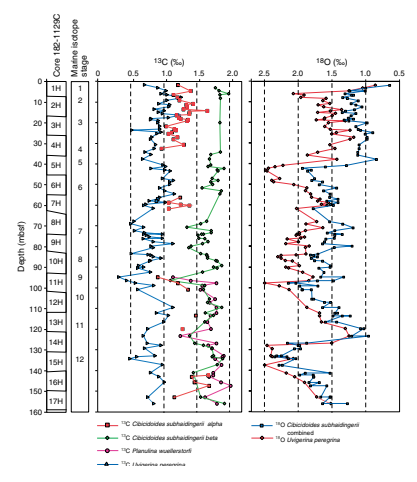


D.A. FEARY ET AL.

of magnitude faster than rates measured during lowstand or highstand phases. This indicates that when the vast adjacent shelf is initially flooded, there is a pulse of sediment production and off-shelf export that decreases toward peak flooding.

Alternating wackestone-packstone units, tentatively identified as cycles, were also described from the western transect by Simo and Slatter (this volume) for Site 1130 and by Brooks et al. (this volume) for Sites 1130 and 1132. Brooks et al. (this volume) document alternating olivegray (aragonite, HMC dominant, and coarser) and light gray (lowmagnesium calcite [LMC] dominant and finer) sediment that together form one cycle. The uppermost $50 \mathrm{~m}$ at Site 1130 and uppermost $150 \mathrm{~m}$ at Site 1132 are sandier than underlying sediments, due to the increasing influence of the adjacent bryozoan reef mounds. The cycles described by Simo and Slatter (this volume) are packstone-wackestone couplets, with the coarser material representing the lower sea level part of the cycle and the finer material representing the higher sea level component. These cycles are younger than the cycles described by Saxena and Betzler (2003) and are interpreted as reflecting a precessionforced (100 k.y.) signal. These two studies suggest that the cycle frequency change from obliquity forced to precession forced, defining the Mid-Pleistocene Revolution (Berger and Jansen, 1994), can be detected in the expanded sedimentary succession of the Great Australian Bight.

\section{Bryozoan Reef Mounds}

The confirmation that mound features visible on seismic data (Fig. F7) within the Pleistocene sedimentary sequence along the upper slope in the Great Australian Bight (Feary and James, 1995, 1998) are bryozoan reef mounds is one of the major findings of Leg 182 (James et al., $2000,2004)$. Despite bryozoan mounds having long been known to exist in the middle to late Paleozoic, such features have never before been described from the "modern" ocean. Although prominent in seismic data from the western Great Australian Bight (Feary and James, 1998), these mounds were not determined to be in situ skeletal accumulations until cored at three Leg 182 sites $(1129,1131$, and 1132).

The mounds are unlithified and consist of a diverse suite of cyclostome and cheilostome bryozoans comprising $~ 80$ genera that are dominated by fenestrate, flat robust branching, encrusting, nodulararborescent, and delicate branching growth forms (Fig. F8) (Bone and James, 2002; James et al., 2004). The packstone matrix comprises authochthonous and allochthonous sand-sized bryozoans, benthic and planktonic foraminifers, serpulids, coralline algae, sponge spicules, peloids, and variable glauconite and quartz grains, together with mudsized octracodes, tunicate spicules, bioeroded sponge chips, and coccoliths. The mounds are covered with a thin, 7- to 10-m mudstone to rudstone veneer, clearly indicating that these buildups are not growing today. AMS and U/Th dating (James et al., 2004), together with oxygen and carbon isotopes from benthic foraminifers (Holbourn et al., 2002) and bryozoans (Machiyama et al., this volume) associated with the mounds, demonstrates that mound growth was restricted to glacial episodes when sea level was low. Mound accumulation was relatively rapid (30-67 cm/k.y.) and locally punctuated by firmgrounds and hardgrounds. Each 5- to 10-m-thick episode of mound growth exhibits a vertical zonation-from floatstone dominated by delicate branching bryozoans, to floatstone characterized by increased bryozoan numbers and diversity, to floatstone and rudstone dominated by delicate branch-
F7. Bryozoan mounds, p. 25.

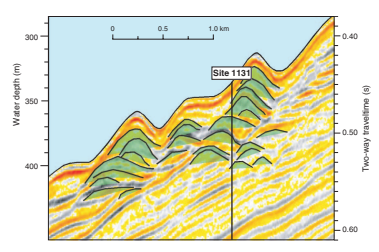

F8. Bryozoan proportions, p. 26.

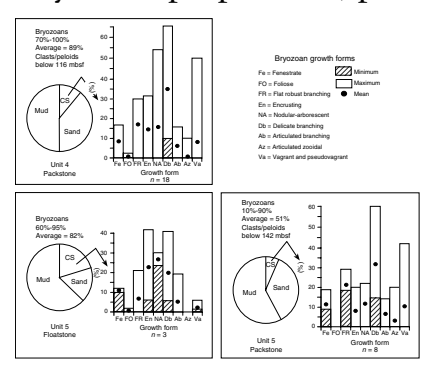


D.A. FEARY ET AL.

ing and fenestrate/flat robust bryozoans-that reflects the response of the bryozoan-dominated community to changing oceanography (James et al., 2004). The upper surfaces of mounds are sharp erosional surfaces or firmgrounds.

Seismic data also show that these mounds occur throughout the Pleistocene succession (Figs. F4, F5), indicating cyclic recurrence of the specific sea level and other oceanographic parameters that controlled mound growth. During glacial periods, the lowered sea level, weakened Leeuwin Current, and increased upwelling provided enhanced carbon flux and nutrients, contributing to prolific bryozoan growth and mound development (James et al., 2000; Holbourn et al., 2002). Alternatively, increased nutrient supply and enhanced primary productivity may have been enhanced by northward movement of the Subtropical Convergence Zone (James et al., 2004) (see Fig. F9). The mounds probably grew in paleowater depths ranging from 100 to $240 \mathrm{~m}$ (James et al., 2000, 2004). The relatively warm Leeuwin Current intensified during highstand interglacial periods, stimulating downwelling and thus reducing the trophic resources to the mound community. As a result, the environment became a largely deeper-water depositional slope mantled by sediment swept off the platform, together with minor biofragmental sediment generated in place, and the mounds became buried.

\section{Geochemistry and Diagenesis}

A significant and completely unpredicted discovery during Leg 182 drilling was the presence of brine within upper slope sediments with salinities as high as $106 \%$. These elevated salinities are associated with the highest $\mathrm{H}_{2} \mathrm{~S}$ concentrations (15\%) ever measured during any Deep Sea Drilling Project (DSDP) or ODP leg (Swart et al., 2000). High levels of $\mathrm{CH}_{4}(50 \%)$ and $\mathrm{CO}_{2}(70 \%)$ were also measured, together with high alkalinity levels (137 $\mathrm{mM})$.

The high $\mathrm{H}_{2} \mathrm{~S}$ concentrations result from the oxidation of organic matter by sulfate-reducing bacteria. Because of the high sulfate concentration within the brine, sulfate does not become depleted with depth (as more typically occurs in marine sediments), allowing extensive sulfate reduction and elevated production of $\mathrm{H}_{2} \mathrm{~S}$ and alkalinity. This chemical environment promotes extensive carbonate recrystallization, resulting in dissolution of more metastable $\mathrm{HMC}$ and aragonite and precipitation of LMC and dolomite (Swart et al., this volume). It is generally thought that warm-water carbonates have a higher diagenetic potential than cool-water carbonates. However, the combination of higher than expected HMC and aragonite content and the chemical environment associated with the presence of the brine indicate that cool-water carbonates may have a higher diagenetic potential than previously appreciated.

Our present hypothesis is that the brines formed during sea level lowstands when much of the existing Eucla Shelf was subaerial and contained large hypersaline lagoons. In this scenario, the arid conditions that presently dominate mid-Australia extended out onto the broad present shelfal zone and caused extensive evaporation from shallow-water lagoons that were subject to recharge by marine waters. A modern analog for this situation is the Lake MacLeod evaporative basin in Western Australia, where marine recharge through a permeable coastal eolianite ridge into an extensive evaporative lagoon has resulted in accumulation of a thick pile of evaporitic sediments from hypersaline waters (Logan, 1987). In the Eucla Shelf situation, we suggest that
F9. Bryozoan mound growth, p. 27.

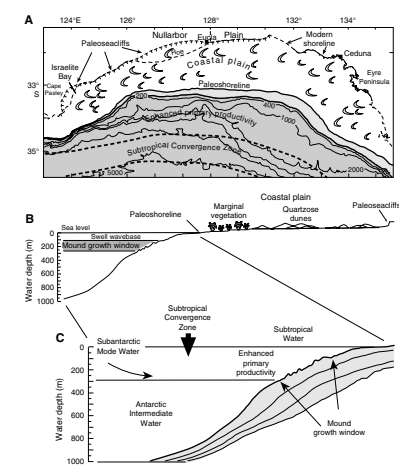


the brines percolated into the underlying sediments and were then forced by hydrostatic head to move seaward into strata lying beneath the present upper slope. The common depth of the brine below present sea level (see Fig. F10) caused the high-salinity fluids to be introduced into sediments of different ages (Swart et al., 2000). As sea level rose, the brines diffused upward as new sediment was deposited. This process would have been repeated numerous times during the Pleistocene.

Swart et al. (2000) argued that $\mathrm{CH}_{4}$ and $\mathrm{H}_{2} \mathrm{~S}$ combined to form disseminated gas hydrates within the upper slope sediments. Although the sites in question (Sites 1127, 1129, and 1131) are located at shallower water depths (200-400 m) and have warmer bottom water temperatures $\left(11^{\circ}-14^{\circ} \mathrm{C}\right)$ than is typical of sites where methane hydrates occur, Swart et al. (2000) suggest that the presence of $\mathrm{H}_{2} \mathrm{~S}$ in the hydrate lattice shifts the hydrate stability field upward to warmer temperatures and lower pressures. By using measured salinities, temperatures, and the maximum gas concentrations, model results indicate that $\mathrm{H}_{2} \mathrm{~S}_{-} \mathrm{CH}_{4}$ hydrates would be thermodynamically stable, at least at Sites 1127 and 1131 (Swart et al., 2000). Although no gas hydrates were recovered during Leg 182 drilling, this may be the result of the difficulty of recovering disseminated hydrates that, because of the presence of high-salinity fluids that would have inhibited large hydrate nodule formation (Sloan, 1998), were more likely to occur than the more easily recovered large hydrate nodules that have been drilled and analyzed during other ODP legs. The disseminated nature of the hydrate might also explain why no bottom-simulating reflector is seen in the seismic profiles. The implications of the Swart et al. (2000) proposal are that $\mathrm{H}_{2} \mathrm{~S}-\mathrm{CH}_{4}$ hydrates may be more common than previously realized, may not have the seismic signature normally associated with $\mathrm{CH}_{4}$ hydrates, and may have the potential to release large quantities of $\mathrm{CH}_{4}$ and $\mathrm{H}_{2} \mathrm{~S}$ into the atmosphere even during small changes of sea level.

Feary et al. (2000) also speculated that there may be a causal relationship between the unusual occurrences of bryozoan-dominated biogenic mounds and the presence of high-salinity brines and high $\mathrm{H}_{2} \mathrm{~S}$ and $\mathrm{CH}_{4}$ dissolved gas contents within the sediment pile. They noted that the saline brine body intersects the seafloor over the depth range corresponding to the biogenic mounds and that the mounds grew during periods of falling and low sea levels. They suggested that this depth zone could have been the site of high-salinity fluid and gas seepage as a consequence of the decreased hydrostatic head that would have accompanied falling sea levels, and that this seepage may have encouraged the enhanced biogenic activity that produced the carbonate mounds.

In typical marine sediments, sulfate reduction and methanogenesis are mutually exclusive processes. Consequently, in most situations methane does not appear in significant concentrations until almost all the dissolved sulfate has been consumed. However, throughout most of the Pleistocene clinoform succession drilled during Leg 182, very high concentrations of microbially generated $\mathrm{H}_{2} \mathrm{~S}$ and $\mathrm{CH}_{4}$ are present in the same depth interval (Mitterer et al., 2001) (Fig. F11). The simultaneous generation of high concentrations of both gases has not been previously observed in normal marine sediments. To explain this occurrence in the context of the thermodynamic and kinetic inhibitions that normally prevent significant co-occurrence of these reactions, Mitterer et al. (2001) suggested that noncompetitive sources of organic material must exist for the two microbial populations that catalyze these reactions. They further hypothesized that amino acids and proteins, which are released from skeletal carbonate material during diagenesis, provide
F10. Chloride contents, p. 28.

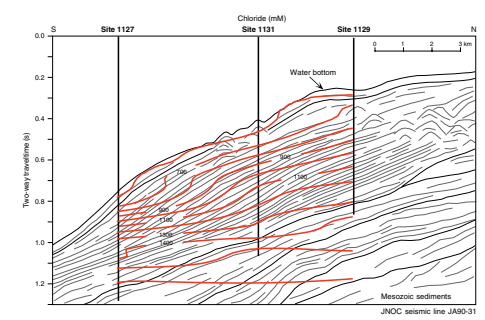

F11. Interstitial water chemistry, p. 29.

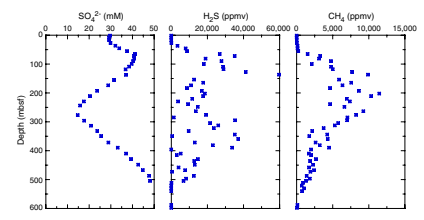


D.A. FEARY ET AL.

the additional organic source that allows methanogenesis to occur simultaneously with sulfate reduction. Additionally, the heavier hydrocarbons $\left(\mathrm{C}_{2}-\mathrm{C}_{6}\right)$ present in the Leg 182 cores (Feary, Hine, Malone, et al., 2000) are also formed as a result of the degradation of the amino acids. Mitterer et al. (2001) note that the co-generation of $\mathrm{H}_{2} \mathrm{~S}$ and $\mathrm{CH}_{4}$ within widespread anoxic carbonate sediment formed during periods of epicontinental sea dominance may have been a contributor to the global greenhouse.

Microbially mediated sulfate reduction in the Great Australian Bight produces a large isotopic fractionation of as much as $72 \%$ o between the coexisting dissolved sulfide and sulfate (Wortmann et al., 2001). This is the first time that such extreme sulfur isotope fractionation has been observed, and this difference (72\%o) is far greater than the assumed biological maximum of $46 \%$ (Kaplan and Rittenberg, 1964). Wortmann et al. (2001) suggest that these extreme isotopic differences between sulfate and the reduced sulfur species may be the result of a single-step microbial fractionation. This extreme fractionation would indicate that the deep biosphere microbial community of sulfate reducers might be quite different from those in the shallow subsurface or within the water column.

In addition to the process-related studies summarized above, three data compilations provide geochemical characterization of Great Australian Bight sediments. Malone (this volume) documents the stable isotopic composition of Pleistocene bulk sediments and dolomite separates from Sites 1127, 1129, and 1131. The carbon isotopic composition of bulk sediments varies narrowly from $0.2 \%$ to $2.2 \%$ Peedee belemnite $(\mathrm{PDB})$ (mean $=1.1 \%$ ), and the oxygen isotopic composition ranges from $0.8 \%$ to $3.2 \%$ PDB $($ mean $=1.9 \%$ ). Dolomite isotopic composition shows considerable variability, with $\delta^{13} \mathrm{C}$ values of $0.4 \% 0-1.9 \%$ $($ mean $=1.3 \% 0)$ and $\delta^{18} \mathrm{O}$ values of $4.0 \% 0-5.9 \%$ (mean $=4.9 \%$ ). Matsuda et al. (this volume) report on the stable isotopic composition of Oligocene and Miocene dolomite and calcite from Site 1132. Calcite $\delta^{13} \mathrm{C}$ values vary from $0.7 \%$ to $1.7 \%$, whereas $\delta^{18} \mathrm{O}$ values range from $0.1 \%$ to $1.4 \%$. Dolomite has a $\delta^{13} \mathrm{C}$ compositional range from $1.2 \%$ o to $2.0 \%$ and a $\delta^{18} \mathrm{O}$ range from $-1.1 \%$ to $2.4 \%$. Emmanuel et al. (this volume) document bulk carbonate elemental chemistry for Sites 11261132, indicating that the carbonate sediments of the Great Australian Bight show the following ranges: $\mathrm{Sr}$ (1000-4000 ppm), Mg (900-27,000 ppm), Mn (4-400 ppm except for Site 1128, where Mn reaches 18,000 $\mathrm{ppm})$, and $\mathrm{Fe}$ (15-1500 ppm). In general, $\mathrm{Sr}$ and $\mathrm{Mg}$ contents are higher in Pleistocene sediment where aragonite and HMC are abundant, whereas older sediments show notable enrichments of $\mathrm{Mn}$ and Fe. Highly elevated Mn concentrations may be the result of contamination of Mn oxide phases.

\section{Early Cenozoic Paleoclimate and Paleoceanography}

Site 1128, located $\sim 200 \mathrm{~km}$ south of the Australian continent in 3874 $\mathrm{m}$ of water, was the only "deepwater" site cored during Leg 182 (Fig. F1). It was designed to address the early Cenozoic history of paleoceanographic and paleoclimatic variability associated with the progressive widening of the Southern Ocean that resulted from the separation of Australia and Antarctica in the late Eocene. A number of workers have shown that there was a significant transition in global climate, together with evidence for the initiation of permanent Cenozoic glaciation in Antarctica, during the late Eocene-early Oligocene (Kennett, 1977; 
D.A. FEARY ET AL.

Miller et al., 1991; Zachos et al., 1992; Flower, 1999). The development of the Circum-Antarctic Current led to the thermal isolation of Antarctica, the expansion of continental ice sheets, and a general global cooling, resulting in prominent positive shifts in both carbon and oxygen isotopic curves. It is within this context that Mallinson et al. (this volume) examined clay mineralogy variations across this time interval at Site 1128. During the early Oligocene, this site was located $\sim 1500 \mathrm{~km}$ from Antarctica at $52^{\circ} \mathrm{S}$.

Mallinson et al. (this volume) use bulk carbonate sediment to reveal a distinct positive isotopic shift at $\sim 33.6-33.48 \mathrm{Ma}$, coinciding with the Oi-1 glacial event of Miller et al. (1991) (Fig. F12). Analysis of relative clay mineralogic variations shows that smectite with varying amounts of illite layers was dominant, followed by kaolinite and discrete illite. By comparing mineralogic variations to the bulk carbon and oxygen isotope values and considering Milankovitch orbital parameters, they reconstruct a paleoclimatic history prior to $33.5 \mathrm{Ma}$ and after $33.4 \mathrm{Ma}$, bracketing the Oi-1 event. They suggest that prior to this event, in an environment of low eccentricity and minimum precession, there was decreased seasonality, decreased winds, and diminished eolian influx with only smectite being introduced from the western Australian craton. Additionally, there was decreased upwelling offshore along the Polar Front. However, after $33.4 \mathrm{Ma}$, as ice sheets were accumulating on Antarctica and in a time of high eccentricity and maximum precession, seasonality and westerly winds increased and eolian influx accelerated with the result that smectite, kaolinite, and illite were transported from the western Australian craton. There may also have been increased fluvial influx from snowmelt in the eastern Australian highlands at this time. Finally, with increased winds, upwelling offshore along the Polar Front was enhanced, causing an elevated carbonate compensation depth.

Interpretation of planktonic foraminiferal assemblages confirms that conditions in the Great Australian Bight were predominantly warmtemperate with subtropical incursions during the middle-late Eocene, cool-temperate in the early Oligocene, and warm-temperate during the late Oligocene (Li, McGowran, and James, this volume). Assemblages indicate cool-temperate conditions during most of the early Miocene, warming to become warm-temperate in the latest early Miocene and warm-temperate to subtropical in the early middle Miocene $(\mathbf{L i}$, McGowran, and Brunner, this volume). This was followed by fluctuating cool- and warm-temperate conditions through the late Miocene, and then by warm-temperate conditions in the early to mid-Pliocene before late Pliocene-Pleistocene cooling.

\section{IMPLICATIONS FOR COOL-WATER CARBONATES}

Leg 182 drill sites were situated largely on the upper slope, a relatively gentle incline that laps down onto a wide submarine terrace, before the seafloor plunges to abyssal depths (Fig. F2). The area can be considered as a distally steepened carbonate ramp (cf. Read, 1985; Burchette and Wright, 1992). The wide continental shelf grades seaward across the shelf break, but the increase in slope is not great. Thus, the region is an excellent analog for carbonate platforms in geologic history that formed in intracratonic and epicratonic basins.
F12. Oi-1 event parameters, p. 30.

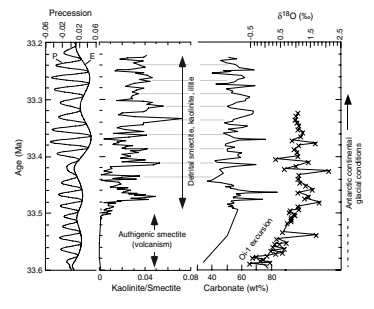


D.A. FEARY ET AL.

The characteristics and origin of cool-water carbonate mid-outer ramp sediments are poorly understood. In general, such deeper-water carbonate environments do not produce much sediment in place, but instead, it is delivered by pelagic fallout and/or resedimentation from shallow water through the actions of dilute to grainy turbidites, grain flows, and debris flows (Coniglio and Dix, 1992). Leg 182 coring provides an abundance of information on the nature of cool-water carbonates in this setting. Sediments are wholly fine grained, resulting from a mixture of pelagic fallout and dilute turbidites with few obvious grain flows and no debrites. They are composed mostly of bryozoans and foraminifers, with accessory coralline algae highlighting their shallowwater provenance. This discovery emphasizes the nature of sediment transport mechanisms in cool-water settings, but it also reflects the widespread uniformity and poor facies differentiation of the shallowwater sediment source area. Resedimentation mechanisms are poorly recorded, largely because of intensive burrowing. The rather muted cyclicity seems again to reflect overall uniformity of the shelf source area, regardless of the position of sea level.

The general perception has been that accumulation rates in coolwater carbonate systems are low, generally <10 cm/k.y. (James, 1997). This is because studies have, by necessity, focused on the shelf rather than the slope. Results from Leg 182 illustrate not only that this is incorrect but also provide the explanation. Sedimentation is clearly partitioned, for although sediment is produced across the depositional system, most is transported off the shelf either seaward to the slope or landward to the strandline. Accumulation rates on the slope rival-and may exceed-those in warm-water carbonate systems. These findings lead to the inevitable conclusion that it is the hydrodynamic characteristics of the depositional system that are critical for generating the neritic inner to mid-ramp continental shelf record. Shallowing of wave base, particularly storm wave base, results in much more sediment accumulating in these shallower areas and less in deeper water. Such results emphasize the hybrid nature of the cool-water carbonate depositional system-it is a "carbonate" environment where sediment is produced everywhere by organic activity, but with similarities to a "terrigenous clastic" environment in that accumulation is controlled by hydrodynamic parameters.

Biogenic mounds (cf. James and Bourque, 1992) have been a component of ramp-style depositional systems throughout geologic history (Wilson, 1975; Tucker and Wright, 1990). Leg 182 coring confirmed that mound features visible in the Pliocene-Pleistocene section on seismic images are bryozoan mounds-the first recognition of such structures in the modern ocean. Overall, the composition of these structures is strikingly similar to older Phanerozoic buildups-muddy, containing a diverse bryozoan assemblage, and rich in calcareous microfossils and sponge spicules. The presence of coralline algal fragments throughout, however, highlights the unexpected role of off-shelf sediment transport in their accretion. In contrast to previous studies, Leg 182 results provide the basis for understanding the nature of paleoceanographic control on mound growth. It is clear that bryozoan mound development coincides with periods of increased primary productivity, particularly during times of low sea level and global glaciation. Overall, trophic resources were increased in the Southern Ocean during lowstands, with localized high-productivity areas at the Subtropical Convergence Zone and in areas of upwelling on the slope (James et al., 2000, 2004). 
D.A. FeARY ET AL.

The mounds themselves strongly resemble the only other exposed and described Cenozoic bryozoan mounds (Surlyk, 1997), confirming the utility of the southern Australian margin findings as the basis for an overall growth model. However, they lack such features as extensive synsedimentary cementation, internal cavities, and obvious microbial influence, attributes that characterize early Mesozoic and older bryozoan mounds (Monty et al., 1995). These differences highlight the Cretaceous change in ocean chemistry that accompanied the evolution of calcareous plankton and decreased overall carbonate saturation. Thus, like modern warm-water carbonates, application of these latest findings to the rock record comes with important caveats.

Cool-water carbonates are dominated by LMC mineralogy, unlike their warm-water counterparts that are rich in high-Mg calcite and aragonite. This difference is important because it means that cool-water carbonates have low diagenetic potential (i.e., they are not subject to early lithification as a consequence of dissolution-precipitation processes and, as a result, are more likely to display the effects of profound mechanical compaction). This concept appears to be true for most shelf sediments (Nelson, 1988; James and Bone, 1989), although evidence from the Cenozoic (James and Bone, 1994; Nicolaides and Wallace, 1997; Nelson and James, 2000) suggests that cementation may be important at omission surfaces in shallow inner-ramp settings. Leg 182 results, however, indicate that aragonite present in slope sediments in cool-water carbonate environments derived mostly from tunicate (ascidian) spicules. This discovery alters the notion of early lithification and implies that these slope sediments do indeed have enough aragonite to result in some relatively early lithification during burial diagenesis.

Leg 182 has opened the door to the somewhat occult sedimentary realm, the cool-water slope-mid- to outer-ramp setting. These drilling results will now allow comparative analysis of ancient temperate carbonates and doubtless lead to reinterpretation of some ancient slope carbonates.

\section{ACKNOWLEDGMENTS}

We gratefully acknowledge the hard work and persistence of our shipboard and shore-based scientific colleagues who produced the body of literature describing Leg 182 drilling results that are synthesized here. We are also most grateful to the Leg 182 marine technicians and ship's officers and crew, who endured stormy seas and extremely trying drilling and logging conditions to accomplish a successful leg. The manuscript has benefited from thoughtful and constructive reviews by Flavio Anselmetti and Gregor Eberli. This research used samples and/or data provided by the Ocean Drilling Program (ODP). ODP is sponsored by the U.S. National Science Foundation (NSF) and participating countries under management of Joint Oceanographic Institutions (JOI), Inc. 


\section{REFERENCES}

Andres, M.S., Bernasconi, S.M., McKenzie, J.A., and Röhl, U., 2003. Southern Ocean deglacial record supports global Younger Dryas. Earth Planet. Sci. Lett., 216:515524.

Berger, W.H., and Jansen, E., 1994. Mid-Pleistocene climate shift: the Nansen connection. In Johannessen, O.M., Muensch, R.D., and Overland, J.E. (Eds.), The Role of the Polar Oceans in Shaping the Global Environment. Geophys. Monogr., 85:295-311.

Bone, Y., and James, N.P., 2002. Bryozoans from temperate Pleistocene deep-water mounds, Great Australian Bight, Australia. In Wise, R., Jackson, J.B.C, Buttler, L., and Jones, M.S. (Eds.), Bryozoan Studies 2001: Lisse (Swets Zeitlinger), 53-59.

Burchette, T.P., and Wright, V.P., 1992. Carbonate ramp depositional systems. Sediment. Geol., 79:3-57.

Coniglio, M., and Dix, G.R., 1992. Carbonate slopes. In Walker, R.G., and James, N.P. (Eds.), Facies Models: Response to Sea Level. Geol. Assoc. Canada, 349-376.

Davies, H.L., Clarke, J.D.A., Stagg, H.M.J., Shafik, S., McGowran, B., Alley, N.F., and Willcox, J.B., 1989. Maastrichtian and younger sediments from the Great Australian Bight. Rep.-Bur. Miner. Resour. Geol. Geophys. (Aust.), 288.

Fairbanks, R.G., 1989. A 17,000-year glacio-eustatic sea level record: influence of glacial melting rates on the Younger Dryas event and deep-ocean circulation. Nature, 342:637-642.

Feary, D.A., Hine, A.C., Malone, M.J., et al., 2000. Proc. ODP, Init. Repts., 182 [CDROM]. Available from: Ocean Drilling Program, Texas A\&M University, College Station, TX 77845-9547, U.S.A.

Feary, D.A., and James, N.P., 1995. Cenozoic biogenic mounds and buried Miocene (?) barrier reef on a predominantly cool-water carbonate continental margin, Eucla Basin, western Great Australian Bight. Geology, 23:427-430.

, 1998. Seismic stratigraphy and geological evolution of the Cenozoic, coolwater Eucla Platform, Great Australian Bight. AAPG Bull., 82:792-816.

Feary, D.A., James, N.P., Swart, P.K., Isern, A.R., Hine, A.C., and Malone, M.J., 2000. Cool-water carbonate mounds and saline fluid flow on the southern Australian margin-is there a causal relationship? Eos, Trans. Am. Geophys. Union, 81 (Suppl.):OS51E-08. (Abstract)

Flower, B.P., 1999. Cenozoic deep-sea temperatures and polar glaciation: the oxygen isotope record. In Barrett, P., and Orombelli, G. (Eds.), Proceedings of the Workshop: Geological Records of Global and Planetary Changes. Terra Antart. Rep., 3:27-42.

Fuller, M., Molina-Garza, R., Antretter, M., and Lichowski, F., 2003. Magnetostratigraphy of the Plio-Pleistocene carbonate section of the Great Australian Bight. Aust. J. Earth Sci., 50:447-466.

Hegarty, K.A., Weissel, J.K., and Mutter, J.C., 1988. Subsidence history of Australia's southern margin: constraints on basin models. AAPG Bull., 72:615-633.

Hine, A.C., Feary, D.A., Malone, M.J., Andres, M., Betzler, C., Brooks, G.R., Brunner, C.A., Fuller, M.D., Holbourn, A.E., Huuse, M., Isern, A.R., James, N.P., Ladner, B.C., Li, Q., Machiyama, H., Mallinson, D.J., Matsuda, H., Mitterer, R.M., Molina, G.R.S., Robin, C., Russell, J.L., Shafik, S., Simo, J.A.T., Smart, P.L., Spence, G.H., Surlyk, F., Swart, P.K., and Wortmann, U.G., 1999. Research in the Great Australian Bight yields exciting early results. Eos, Trans. Am. Geophys. Union, 80:521, 525-526.

Holbourn, A.E., Kuhnt, W., and James, N.P., 2002. Late Pleistocene bryozoan reef mounds of the Great Australian Bight: isotope stratigraphy and benthic foraminiferal record. Paleoceanography, 17:10.1029/2001PA000643.

Imbrie, J., Hays, J.D., Martinson, D.G., McIntyre, A., Mix, A.C., Morley, J.J., Pisias, N.G., Prell, W.L., and Shackleton, N.J., 1984. The orbital theory of Pleistocene climate: support from a revised chronology of the marine $\delta^{18} \mathrm{O}$ record. In Berger, A., Imbrie, J., Hays, J., Kukla, G., and Saltzman, B. (Eds.), Milankovitch and Climate (Pt. 1): Hingman, MA (D. Riedel Publishing Co.), 269-305. 
James, N.P., 1997. The cool-water carbonate depositional realm. In James, N.P., and Clarke, J.D.A. (Eds.), Cool-Water Carbonates. Spec. Publ._SEPM (Soc. Sediment. Geol.), 56:1-20.

James, N.P., and Bone, Y., 1989. Petrogenesis of Cenozoic temperate water calcarenites, south Australia: a model for meteoric/shallow burial diagenesis of shallow water calcite sediments. J. Sediment. Petrol., 59:191-204.

- 1991 . Origin of a cool-water, Oligo-Miocene deep shelf limestone, Eucla Platform, southern Australia. Sedimentology, 38:323-341.

- 1994 . Paleoecology of cool-water, subtidal cycles in mid-Cenozoic limestones, Eucla platform, southern Australia. Palaios, 9:457-476.

James, N.P., Bone, Y., Collins, L.B., and Kyser, T.K., 2001. Surficial sediments of the Great Australian Bight: facies dynamics and oceanography on a vast cool-water carbonate shelf. J. Sediment. Res., 71:549-567.

James, N.P., Boreen, T.D., Bone, Y., and Feary, D.A., 1994. Holocene carbonate sedimentation on the west Eucla Shelf, Great Australian Bight: a shaved shelf. Sediment. Geol., 90:161-177.

James, N.P., and Bourque, P.-A., 1992. Reefs and mounds. In Walker, R.G., and James, N.P. (Eds.), Facies Models: Response to Sea Level Change. Geol. Assoc. Can., 323-347.

James, N.P., Feary, D.A., Betzler, C., Bone, Y., Holbourn, A.E., Li, Q., Machiyama, H., Simo, J.A., and Surlyk, F., 2004. Origin of late Pleistocene bryozoan reef-mounds, Great Australian Bight. J. Sediment. Res., 74:20-48.

James, N.P., Feary, D.A., Surlyk, F., Simo, J.A., Betzler, C., Holbourn, A.E., Li, Q., Matsuda, H., Machiyama, H., Brooks, G.R., Andres, M.S., Hine, A.C., Malone, M.J., and the ODP Leg 182 Science Party, 2000. Quaternary bryozoan reef mounds in coolwater, upper slope environments, Great Australian Bight. Geology, 28:647-650.

Kaplan, I.R., and Rittenberg, S.C., 1964. Microbiological fractionation of sulfur isotopes. J. Gen. Microbiol., 34:195-212.

Kennett, J.P., 1977. Cenozoic evolution of Antarctic glaciation, the circum-Antarctic Ocean, and their impact on global paleoceanography. J. Geophys. Res., 82:38433860.

Li, Q., James, N.P., and McGowran, B., 2003. Middle and late Eocene Great Australian Bight lithobiostratigraphy and stepwise evolution of the southern Australian continental margin. Aust. J. Earth Sci., 50:113-128.

Li, Q., Simo, J.A., McGowran, B., and Holbourn, A., 2004. The eustatic and tectonic origin of Neogene unconformities from the Great Australian Bight. Mar. Geol., 203:57-81.

Logan, B.W., 1987. The MacLeod Evaporite Basin, western Australia: Holocene environments, sediments and geological evolution. AAPG Mem., Vol. 44.

Mallinson, D.J., Flower, B., Hine, A., Brooks, G., and Molina Garza, R., 2003. Paleoclimate implications of high latitude precession-scale mineralogic fluctuations during early Oligocene Antarctic glaciation: the Great Australian Bight record. Global Planet. Change, 39:257-269.

Miller, K.G., Wright, J.D., and Fairbanks, R.G., 1991. Unlocking the Ice House: Oligocene-Miocene oxygen isotopes, eustasy, and margin erosion. J. Geophys. Res., 96:6829-6848.

Mitterer, R.M., Malone, M.J., Goodfriend, G.A., Swart, P.K., Wortmann, U.G., Logan, G.A., Feary, D.A., and Hine, A.C., 2001. Co-generation of hydrogen sulfide and methane in marine carbonate sediments. Geophys. Res. Lett., 28:3931-3934.

Molina Garza, R.S., and Fuller, M., 2002. Paleolatitudes and magnetostratigraphy for Cenozoic sediments, ODP Leg 182: the Great Australian Bight. Earth, Planets Space, 54:399-413.

Monty, C.L.V., Bosence, D.W.J., Bridges, P.H., and Pratt, B.R. (Eds.), 1995. Carbonate mud-mounds: their origin and evolution. Spec. Publ. Int. Assoc. Sedimentol., Vol. 23.

Nelson, C.S., 1988. An introductory perspective on non-tropical shelf carbonates. Sediment. Geol., 60:3-12. 
D.A. FeARY ET AL.

LEG 182 SYNTHESIS: EXPOSED SECRETS OF THE GAB

Nelson, C.S., and James, N.P., 2000. Marine cements in mid-Tertiary cool-water shelf limestones of New Zealand and southern Australia. Sedimentology, 47:609-630.

Nicolaides, S., and Wallace, M., 1997. Submarine cementation and subaerial exposure in Oligo-Miocene temperate carbonates, Torquay Basin, Australia. J. Sediment. Res., 67:397-410.

Read, J.F., 1985. Carbonate platform facies models. AAPG Bull., 69:1-21.

Saxena, S., and Betzler, C., 2003. Genetic sequence stratigraphy of cool water slope carbonates (Pleistocene Eucla Shelf, southern Australia). Int. J. Earth Sci., 92:482493.

Schlager, W., 1981. The paradox of drowned reefs and carbonate platforms. Geol. Soc. Am. Bull., 92:197-211.

Sloan, D., 1998. Clathrate Hydrates of Natural Gases (2nd ed.): New York (Marcel Dekker).

Stagg, H.M.J., Cockshell, C.D., Willcox, J.B., Hill, A.J., Needham, D.J.L., Thomas, B., O'Brien, G.W., and Hough, L.P., 1990. Basins of the Great Australian Bight Region: Geology and Petroleum Potential. Rep.-Bur. Mineral Resour. Geol. Geophys. (Aust.), 5.

Surlyk, F., 1997. A cool-water carbonate ramp with bryozoan mounds: Late Cretaceous-Danian of the Danish Basin. In James, N.P., and Clarke, J.D.A. (Eds.), Coolwater Carbonates. Spec. Publ._SEPM (Soc. Sediment. Geol.), 56:293-307.

Swart, P.K., Wortmann, U.G., Mitterer, R.M., Malone, M.J., Smart, P.L., Feary, D.A., and Hine, A.C., 2000. Hydrogen sulfide-rich hydrates and saline fluids in the continental margin of South Australia. Geology, 28:1039-1042.

Tucker, M.E., and Wright, P.V., 1990. Carbonate Sedimentology: Oxford (Blackwell Sci. Publ.).

Willcox, J.B., Stagg, H.M.J., and Davies, H.L., 1988. Rig seismic research cruises 10 and 11: geology of the central Great Australian Bight region. Rep.-Bur. Mineral Resour. Geol. Geophys. (Aust.), 286.

Wilson, J.L., 1975. Carbonate Facies in Geologic History: Berlin (Springer-Verlag).

Wortmann, U.G., Bernasconi, S.M., and Böttcher, M.E., 2001. Hypersulfidic deep biosphere indicates extreme sulfur isotope fractionation during single-step microbial sulfate reduction. Geology, 29:647-650.

Zachos, J., Breza, J., and Wise, S.J., 1992. Early Oligocene ice-sheet expansion on Antarctica: sedimentological and isotopic evidence from Kerguelen Plateau. Geology, 20:569-573. 
D.A. FeARY ET AL.

LEG 182 SYNTHESIS: EXPOSED SECRETS OF THE GAB

Figure F1. Locations of Leg 182 drill sites in the western Great Australian Bight relative to the Eucla Shelf edge and the Eyre Terrace. Red lines through Sites 1127, 1131, and 1129 (eastern transect) and Sites 1130 and 1132 (western transect) show locations of seismic reflection data presented in Figures F4, p. 22, and F5, p. 23.

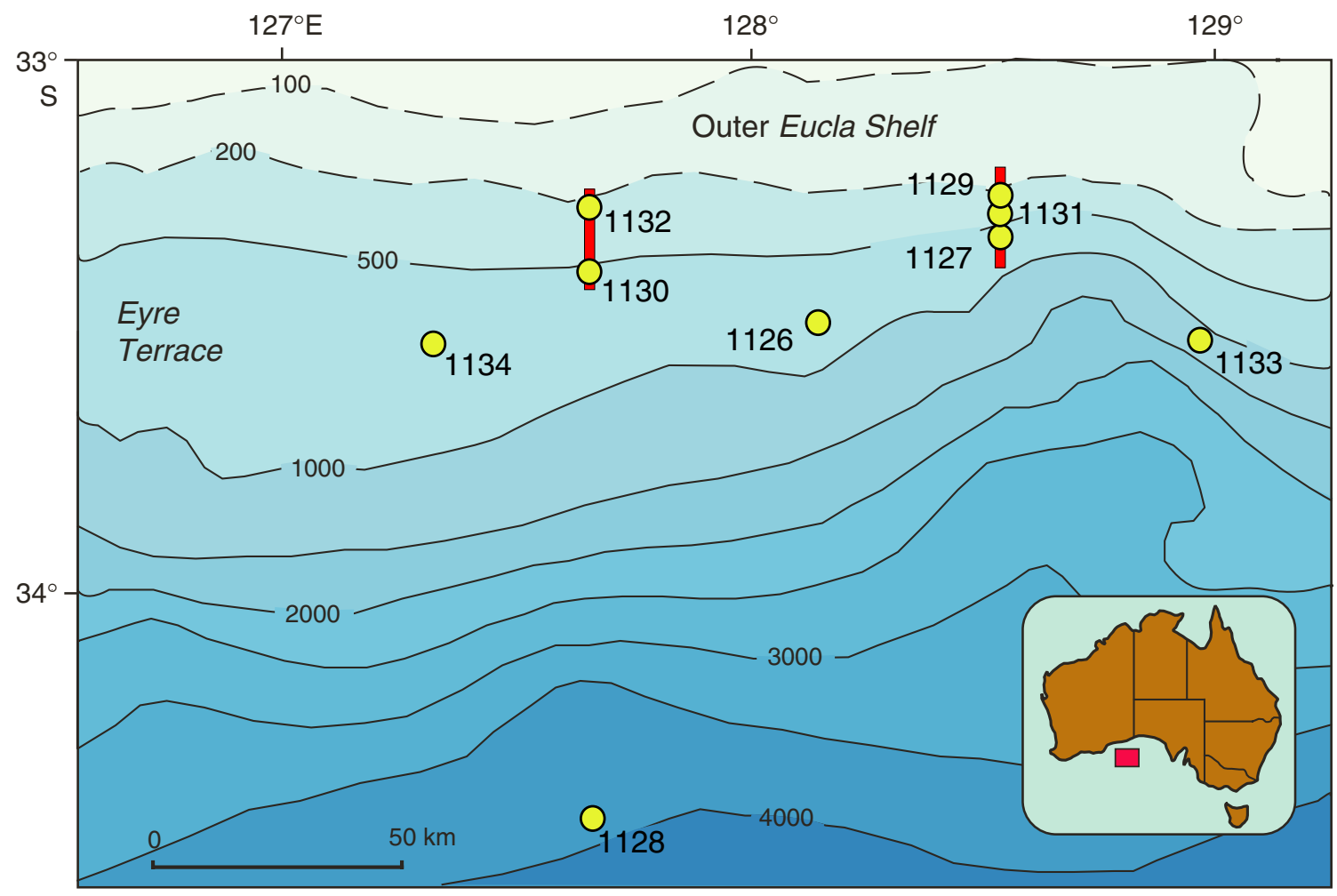


D.A. FEARY ET AL.

LEg 182 SYNTHESIS: EXPOSED SECRETS OF THE GAB

Figure F2. Schematic north-south diagram from the onshore Nullarbor Plain to the upper continental slope across the Eyre Terrace (nominally along longitude $128^{\circ} \mathrm{E}$ ), showing the distribution and internal relationships of seven Cenozoic sequences defined from seismic data, overlying Mesozoic synrift siliciclastic sequences and Precambrian crystalline basement (modified after Feary and James, 1998). Vertical scales are approximate.

$\mathrm{S}$

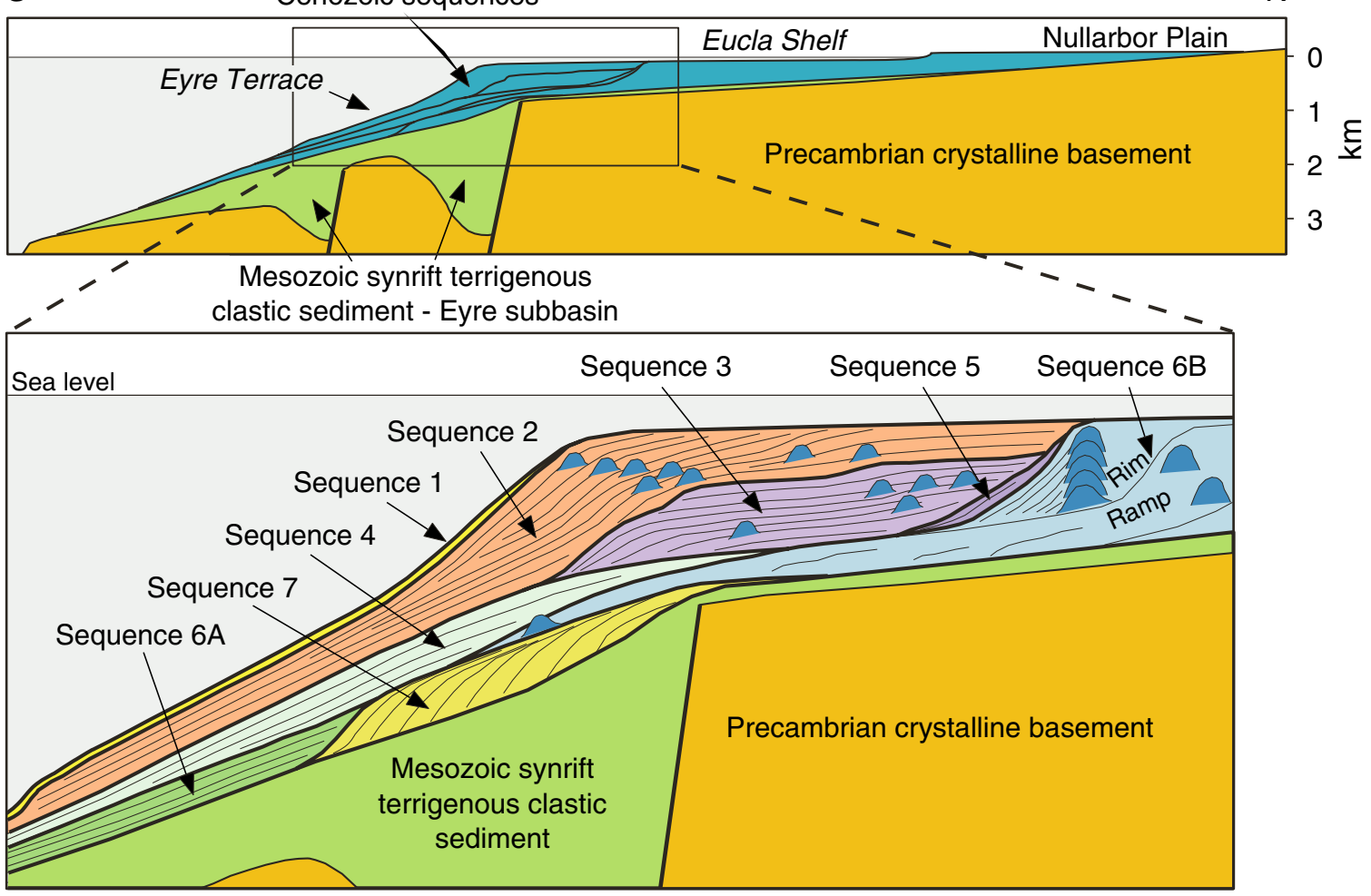


D.A. FeARY ET AL.

LEG 182 SYNTHESIS: EXPOSED SECRETS OF THE GAB

Figure F3. Schematic summary of seismic stratigraphy for all Leg 182 sites except deepwater Site 1128. Note the numerous hiatal surfaces throughout most sequences. Based on data from Li, McGowran, and James (this volume); Li, McGowran, and Brunner (this volume); and Li et al. (2003, 2004). Sequence colors correlate with Figure F2, p. 20.

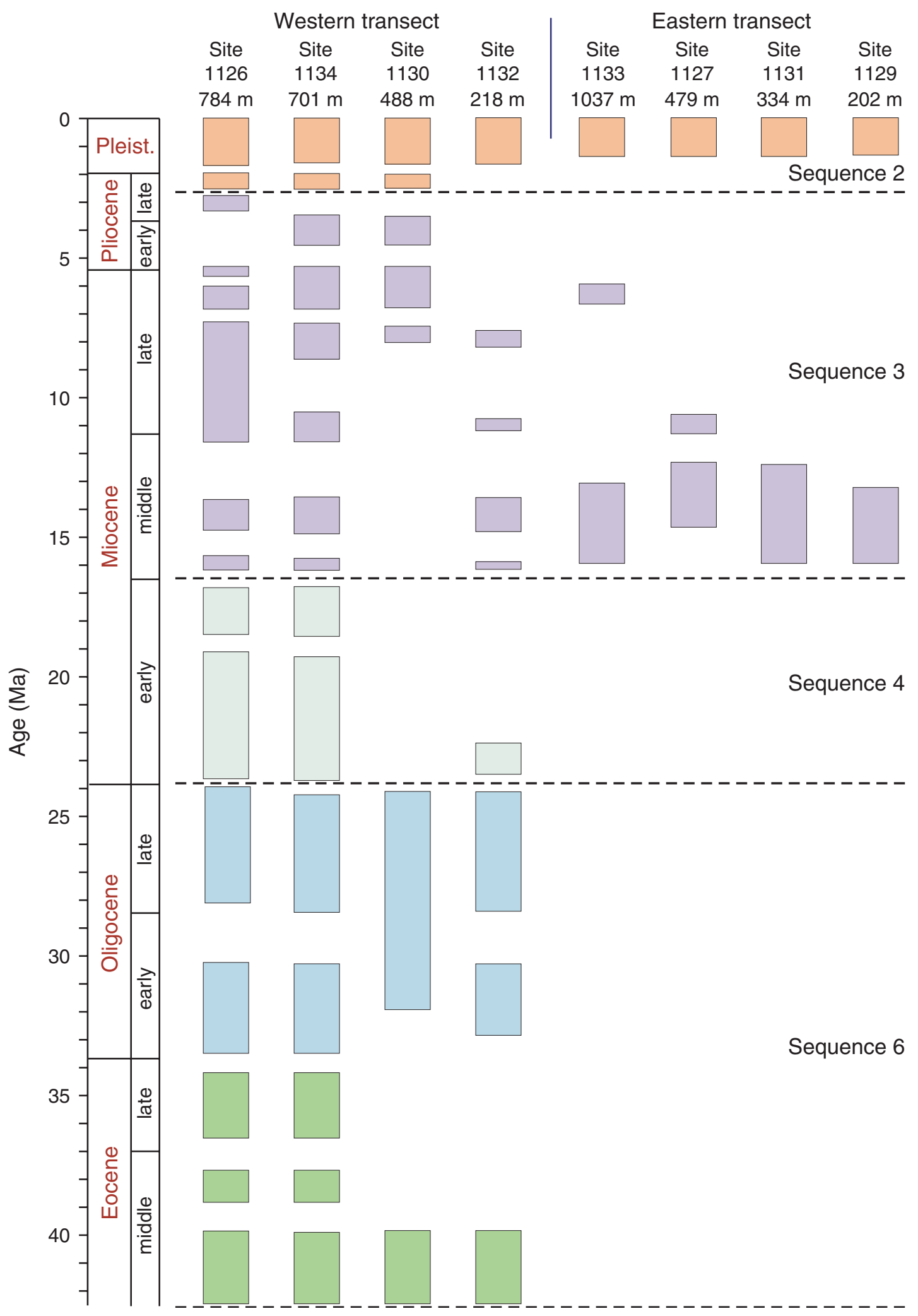


Figure F4. Seismic reflection image (seismic line AGSO-169/05a) of the eastern drilling transect, showing the thick Pleistocene clinoform wedge underlying the modern outermost shelf and upper slope and the location of Sites 1127, 1129, and 1131. Bryozoan mounds are visible as individual mounds and as stacked mound complexes immediately below the seafloor seaward of the shelf edge and also buried within the sediment wedge. Dashed box shows area enlarged in Figure F7, p. 25.

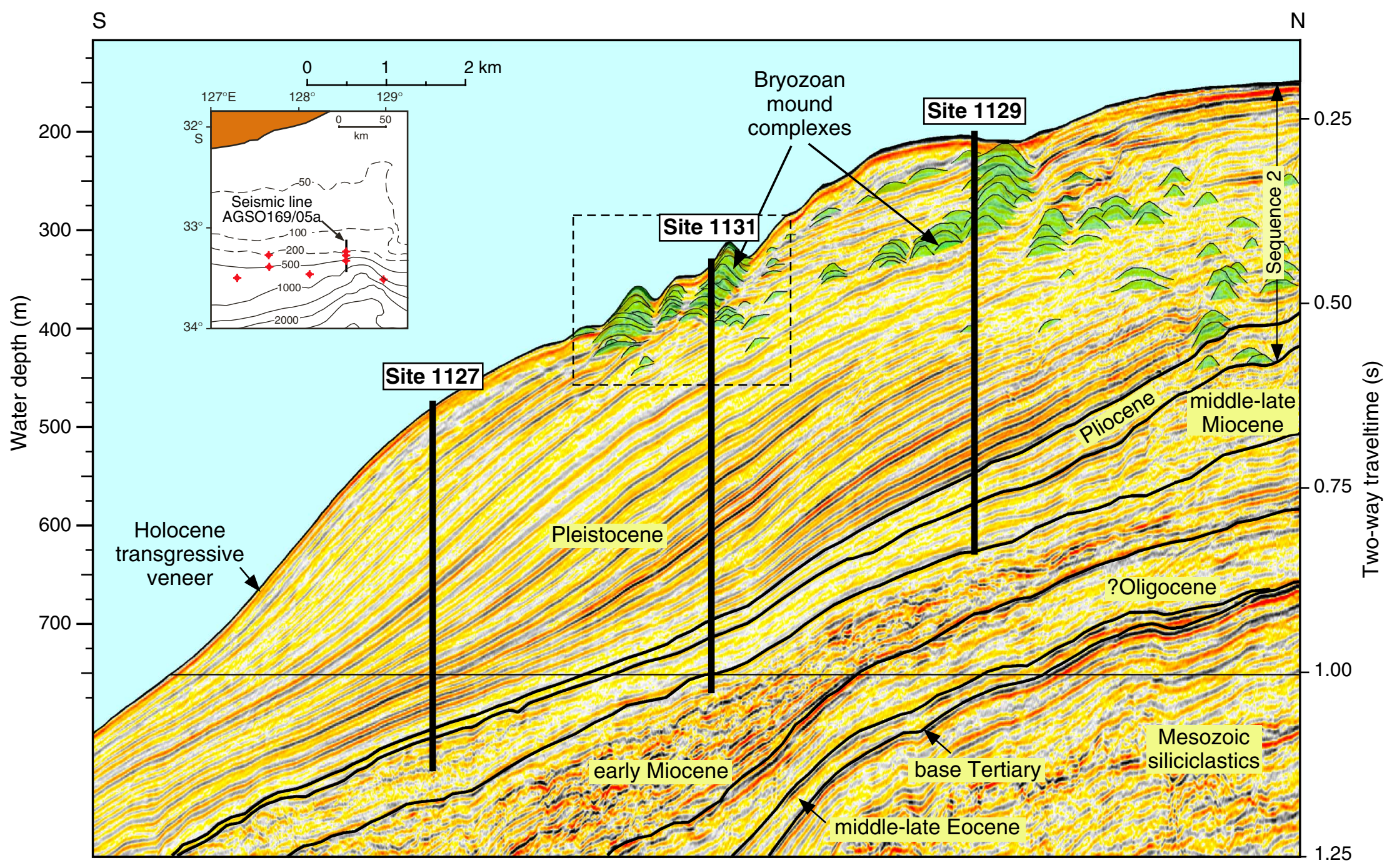


Figure F5. Seismic reflection image (seismic line AGSO-169/13a) of the western drilling transect, showing the thick Pleistocene clinoform wedge underlying the modern outermost shelf and upper slope and the location of Sites 1130 and 1132.

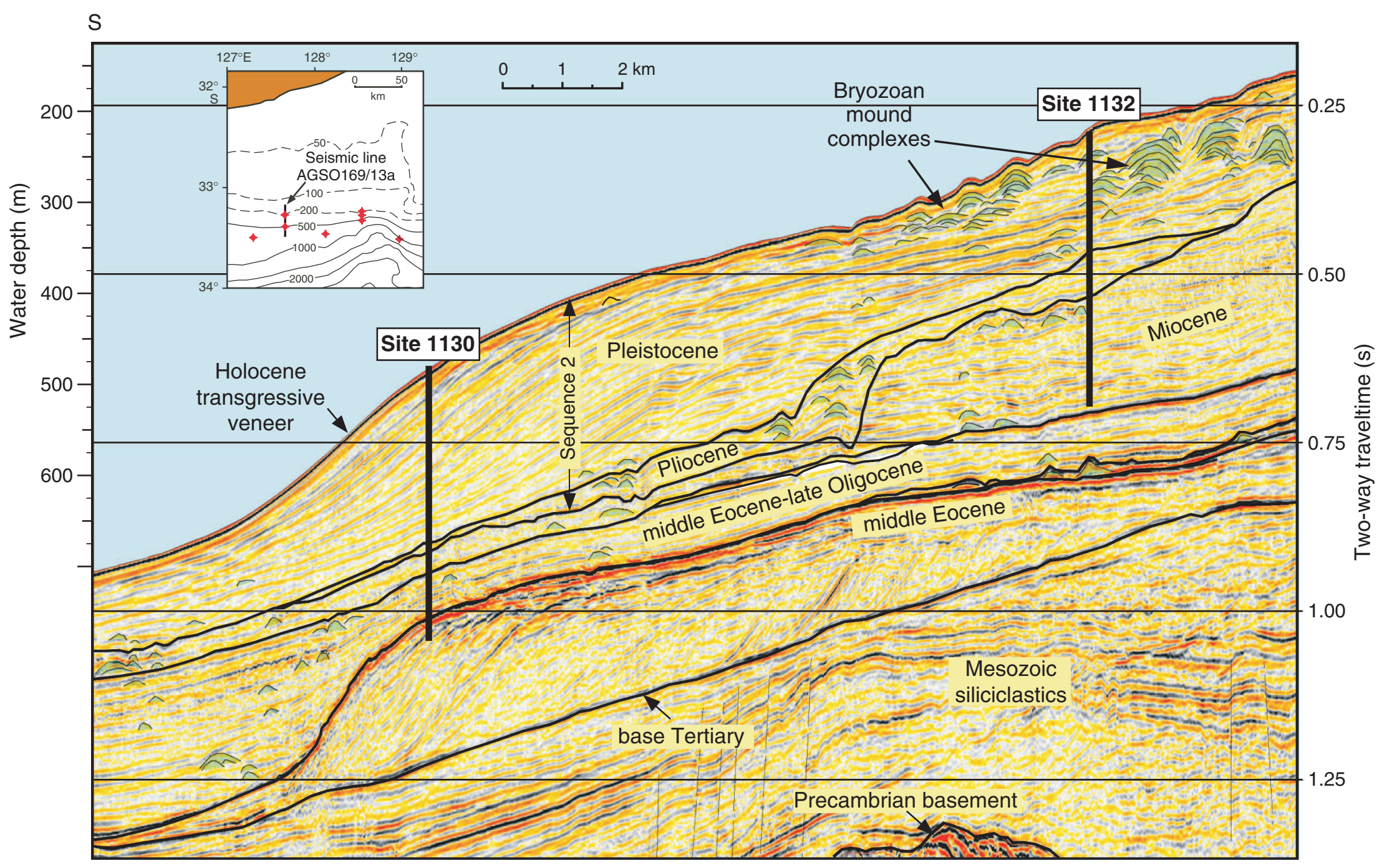


D.A. FEARY ET AL.

LEG 182 SYNTHESIS: EXPOSED SECRETS OF THE GAB

Figure F6. Isotope events plotted against ${ }^{18} \mathrm{O}$ and ${ }^{13} \mathrm{C}$ profiles (vs. Peedee belemnite) in upper Pleistocene cores from Site 1129 (after Holbourn et al., 2002).

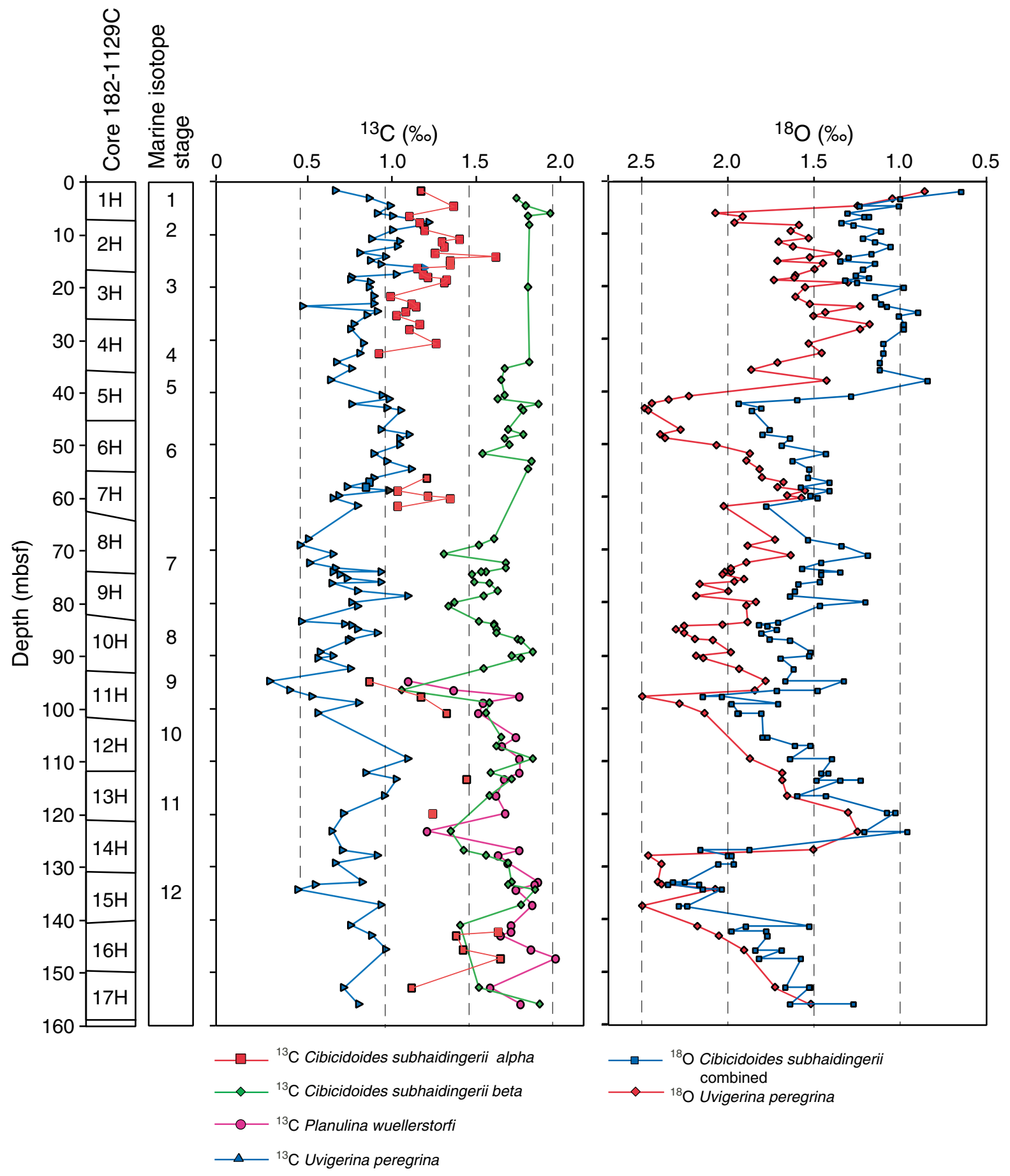


D.A. FeARY ET AL.

LEG 182 SYNTHESIS: EXPOSED SECRETS OF THE GAB

Figure F7. Seismic reflection image (seismic line AGSO-169/05a) showing detail of bryozoan mounds and mound complexes in the vicinity of Site 1131. Location of this image is shown in Figure F4, p. 22.

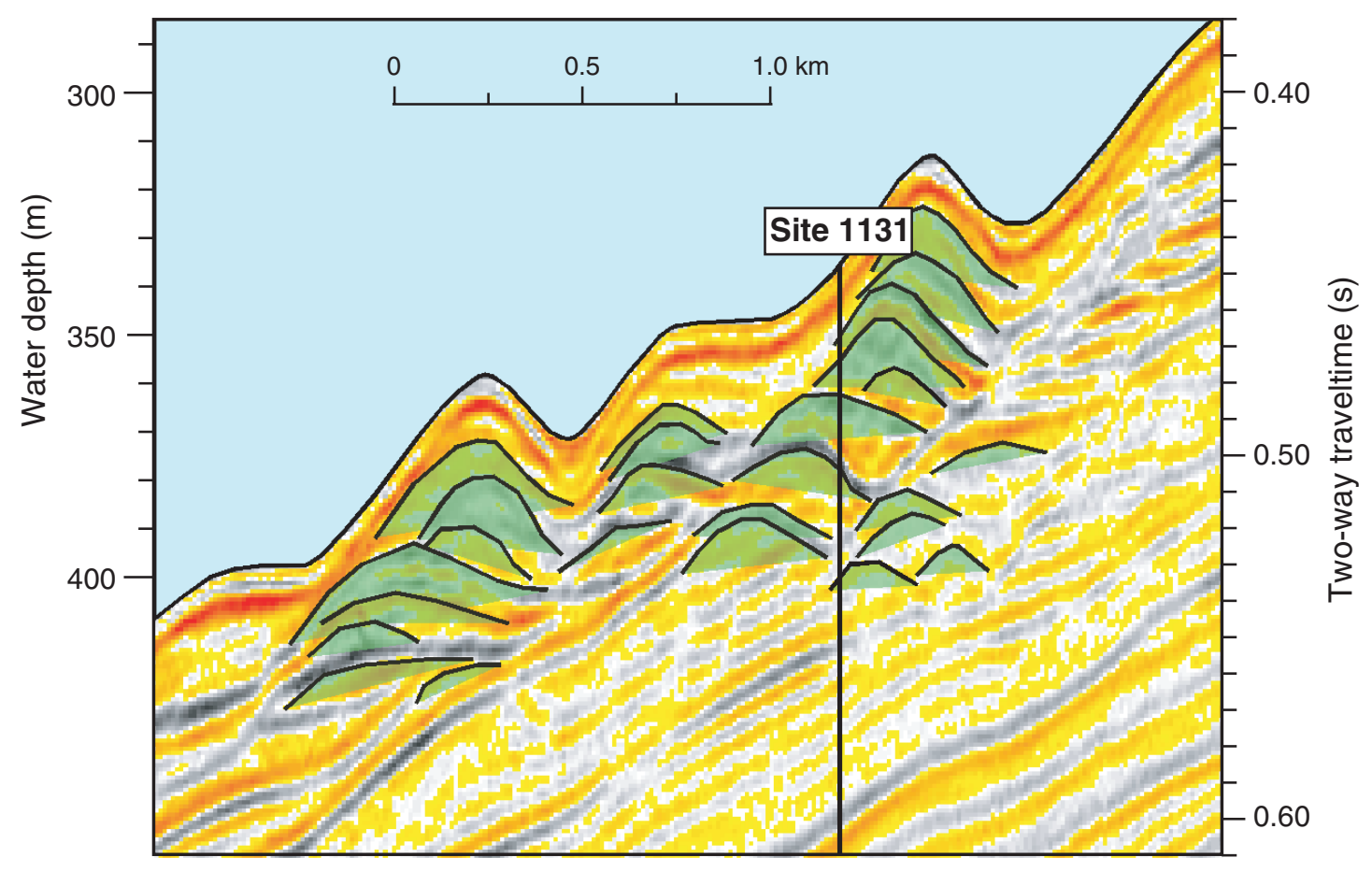


D.A. FEARY ET AL.

LEG 182 SYNTHESIS: EXPOSED SECRETS OF THE GAB

Figure F8. Relative proportions of bryozoans in different lithologies from Site 1129 (after James et al., 2004). CS = coarse sediment fraction $(>2 \mathrm{~mm})$.

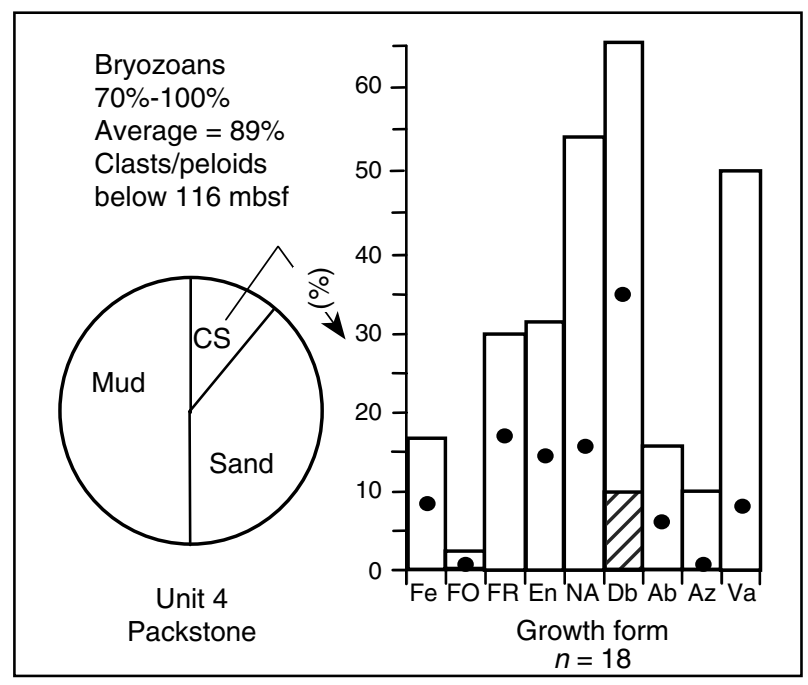

Bryozoan growth forms

$$
\begin{aligned}
& \mathrm{Fe}=\text { Fenestrate } \\
& \mathrm{FO}=\text { Foliose } \\
& \mathrm{FR}=\text { Flat robust branching } \\
& \mathrm{En}=\text { Encrusting } \\
& \mathrm{NA}=\text { Nodular-arborescent } \\
& \mathrm{Db}=\text { Delicate branching } \\
& \mathrm{Ab}=\text { Articulated branching } \\
& \mathrm{Az}=\text { Articulated zooidal } \\
& \mathrm{Va}=\text { Vagrant and pseudovagrant }
\end{aligned}
$$
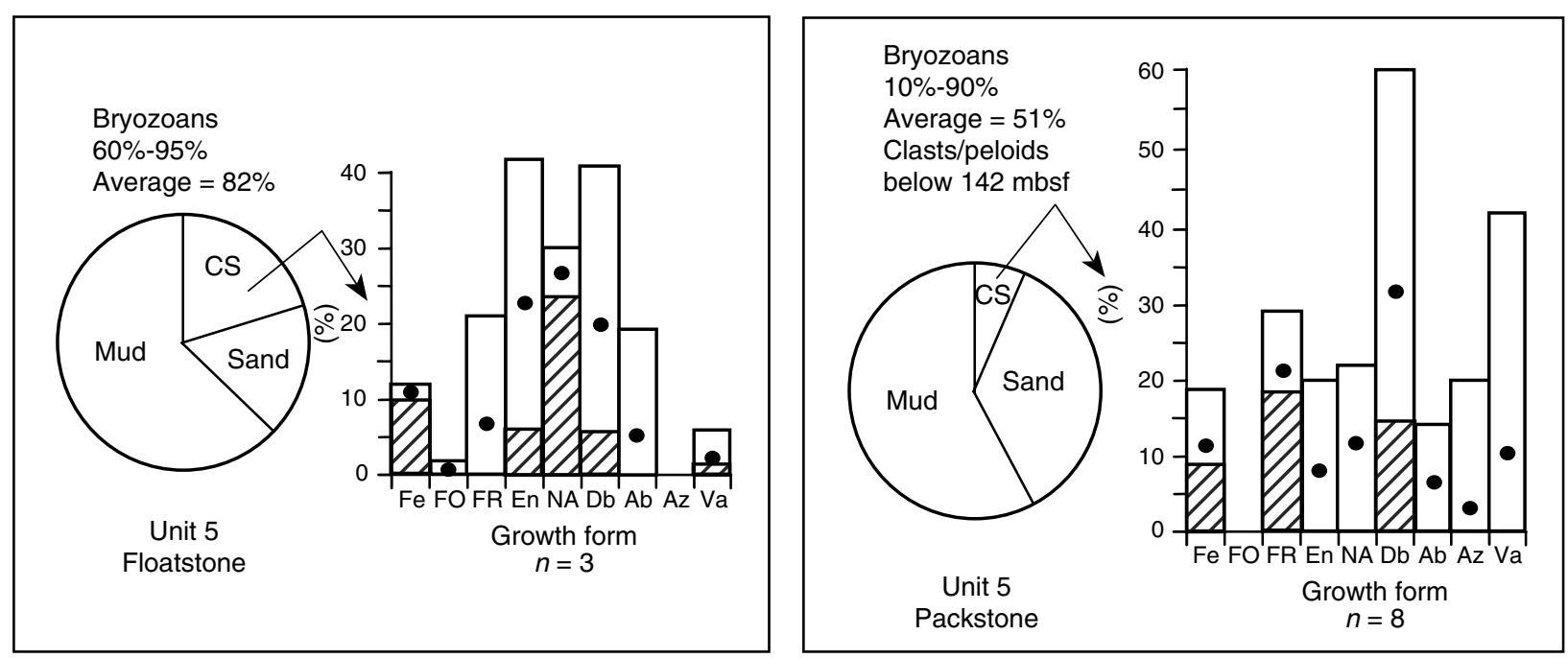
D.A. FeARY ET AL.

LEG 182 SYNTHESIS: EXPOSED SECRETS OF THE GAB

Figure F9. Interpretation of bryozoan mound growth parameters during glacial lowstands (after James et al., 2004). A. Paleogeography showing the wide coastal plain, narrow shelf, possible location of the Subtropical Convergence Zone, and associated zone of enhanced primary productivity. B. Cross section of the coastal plain, shelf, and upper slope, illustrating location of the mound growth window. C. Enlarged cross section showing interpreted paleogeography and the probable location of major water masses.
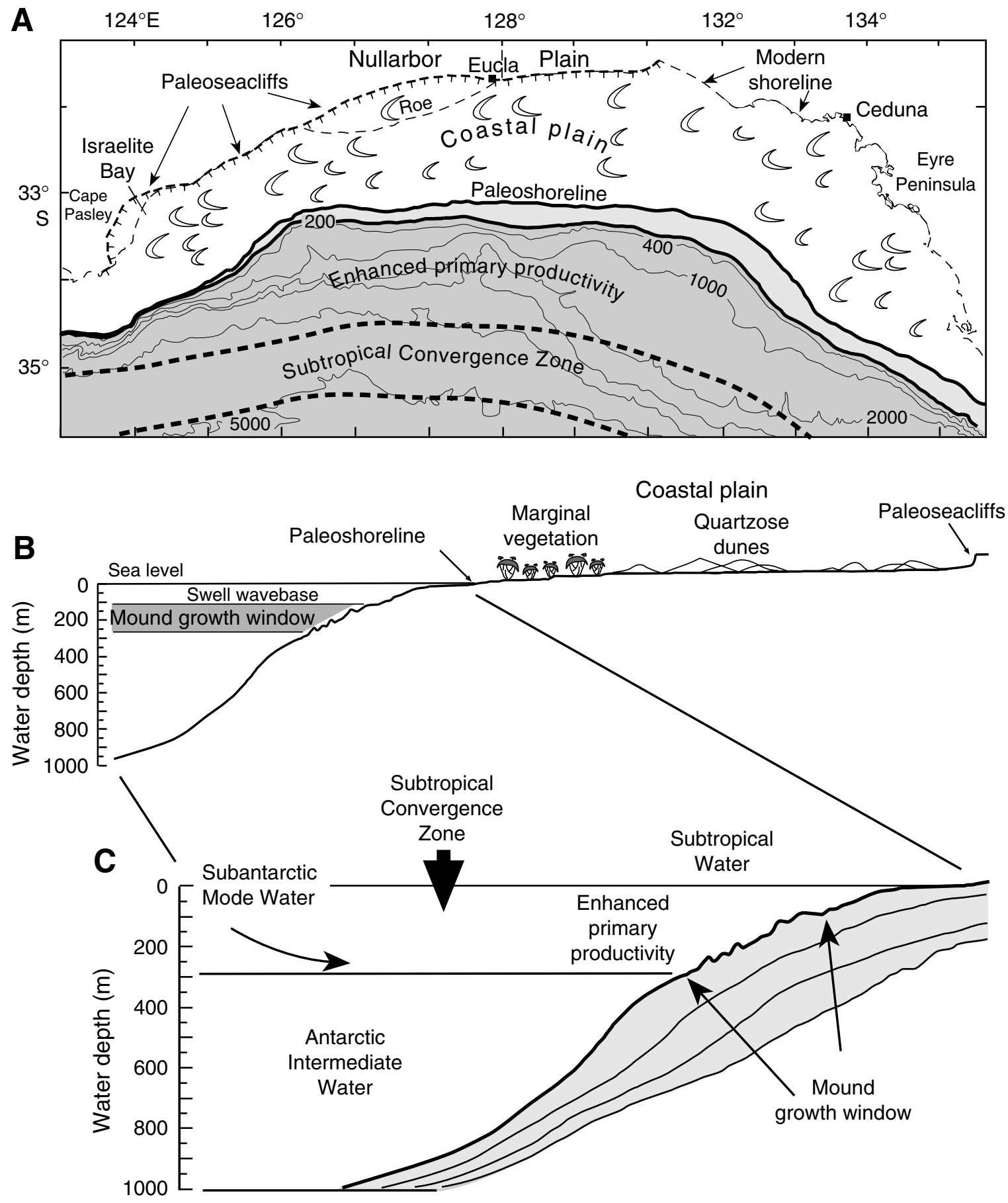
Figure F10. Contour plot showing $\mathrm{Cl}^{-}$concentrations at Sites 1127,1131 , and 1129 (the eastern transect) overlying an interpretation of the seismic line joining the three sites. Note that the lines of equal $\mathrm{Cl}^{-}$concentrations crosscut the seismic sequence and accordingly are consistent with the presence of a subhorizontal brine (after Feary, Hine, Malone, et al., 2000).

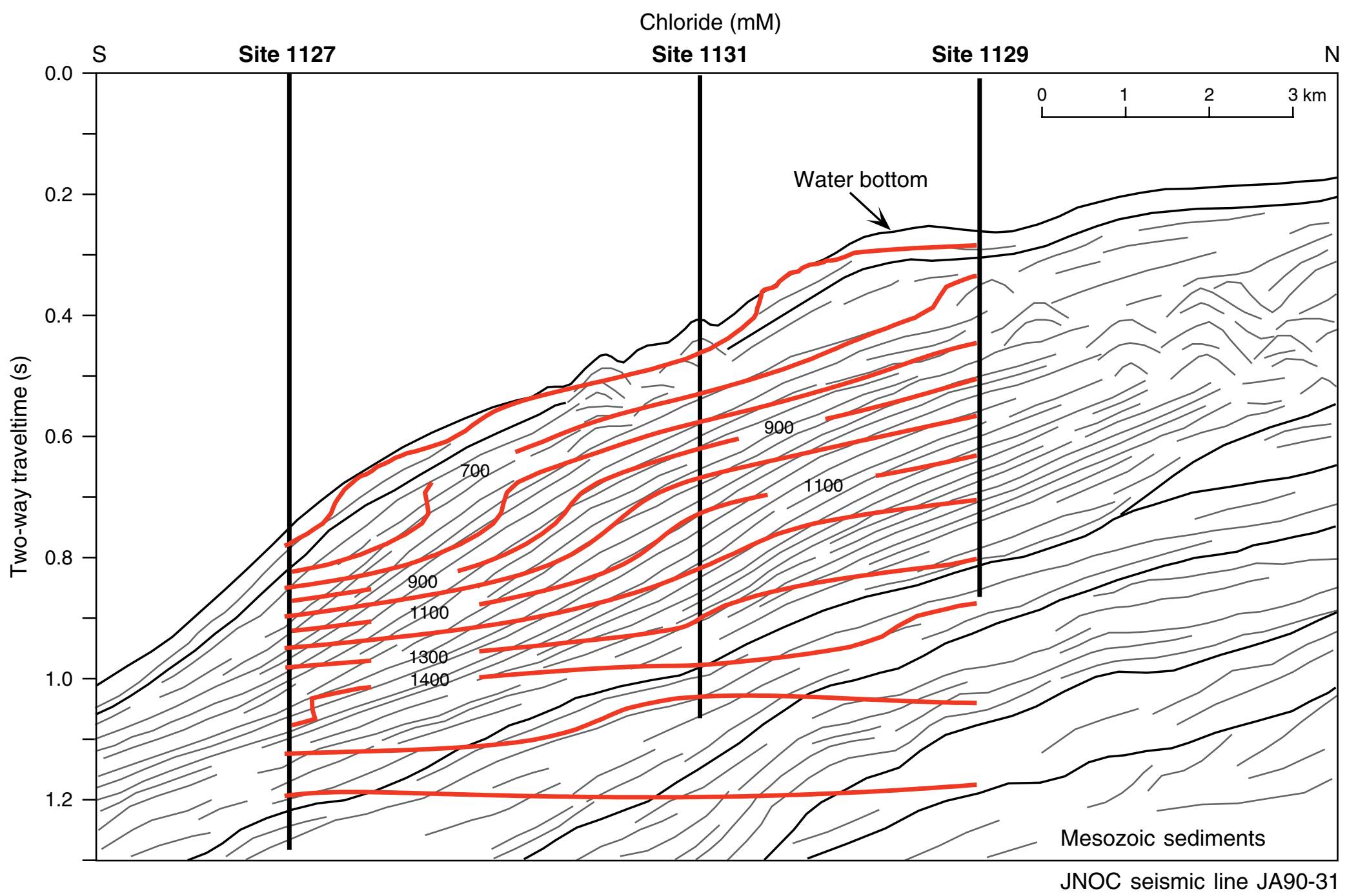


D.A. FeARY ET AL.

LEG 182 SYNTHESIS: EXPOSED SECRETS OF THE GAB

Figure F11. Plot showing interstitial water sulfate, hydrogen sulfide, and methane from Site 1131 vs. depth. Note the co-occurrence of sulfate and methane. The presence of hydrogen sulfide, a by-product of sulfate reduction, indicates that active sulfate reduction and methanogenesis are occurring over the same depth interval (after Mitterer et al., 2001).

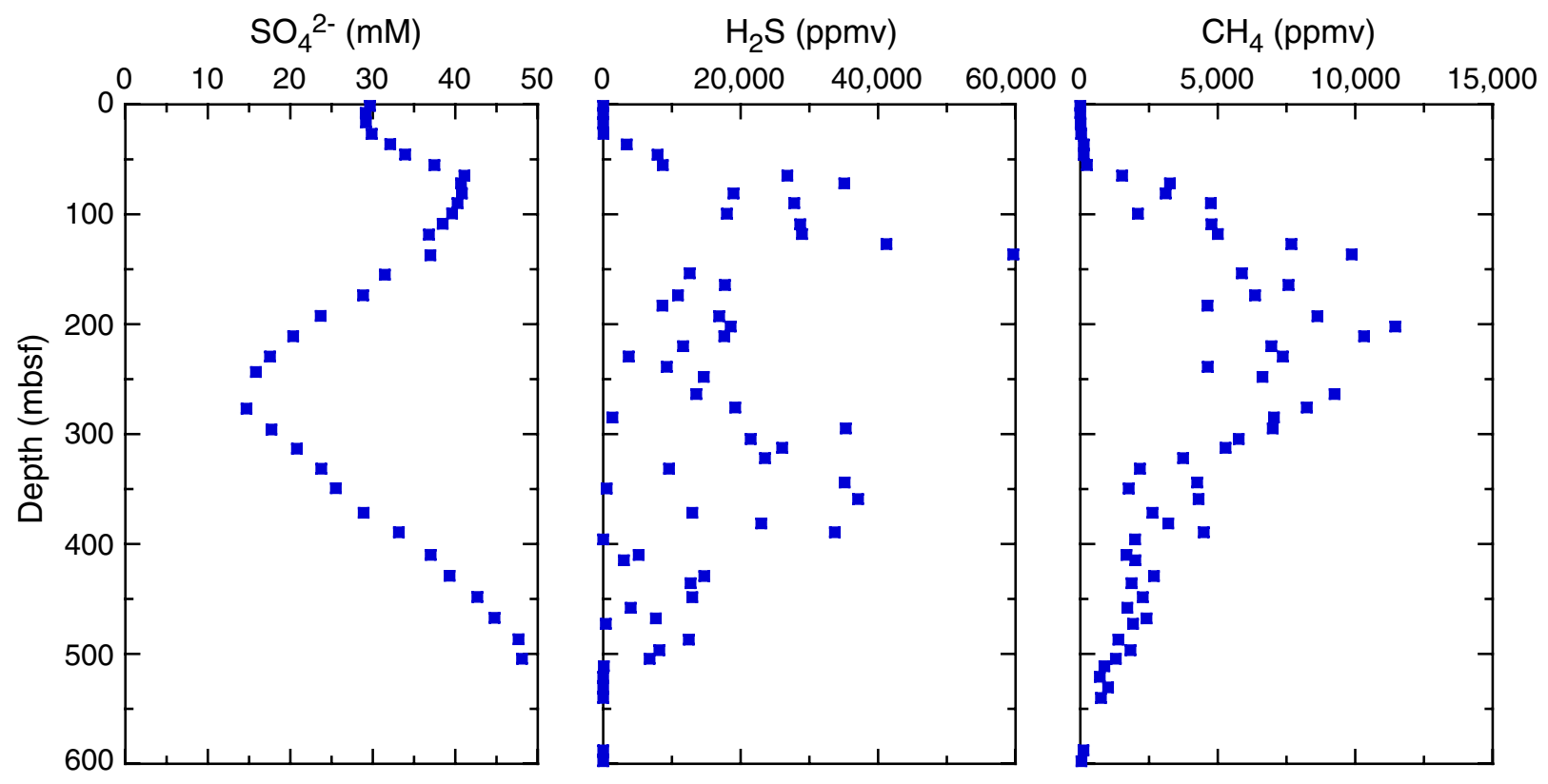


D.A. FeARY ET AL.

LEG 182 SYNTHESIS: EXPOSED SECRETS OF THE GAB

Figure F12. The positive ${ }^{18} \mathrm{O}$ isotopic shift at $\sim 33.6-33.48 \mathrm{Ma}$, coinciding with the Oi-1 glacial event, plotted against carbonate, kaolinite/smectite index, clay facies, and both eccentricity (E) and precession (P) (after Mallinson et al., 2003).

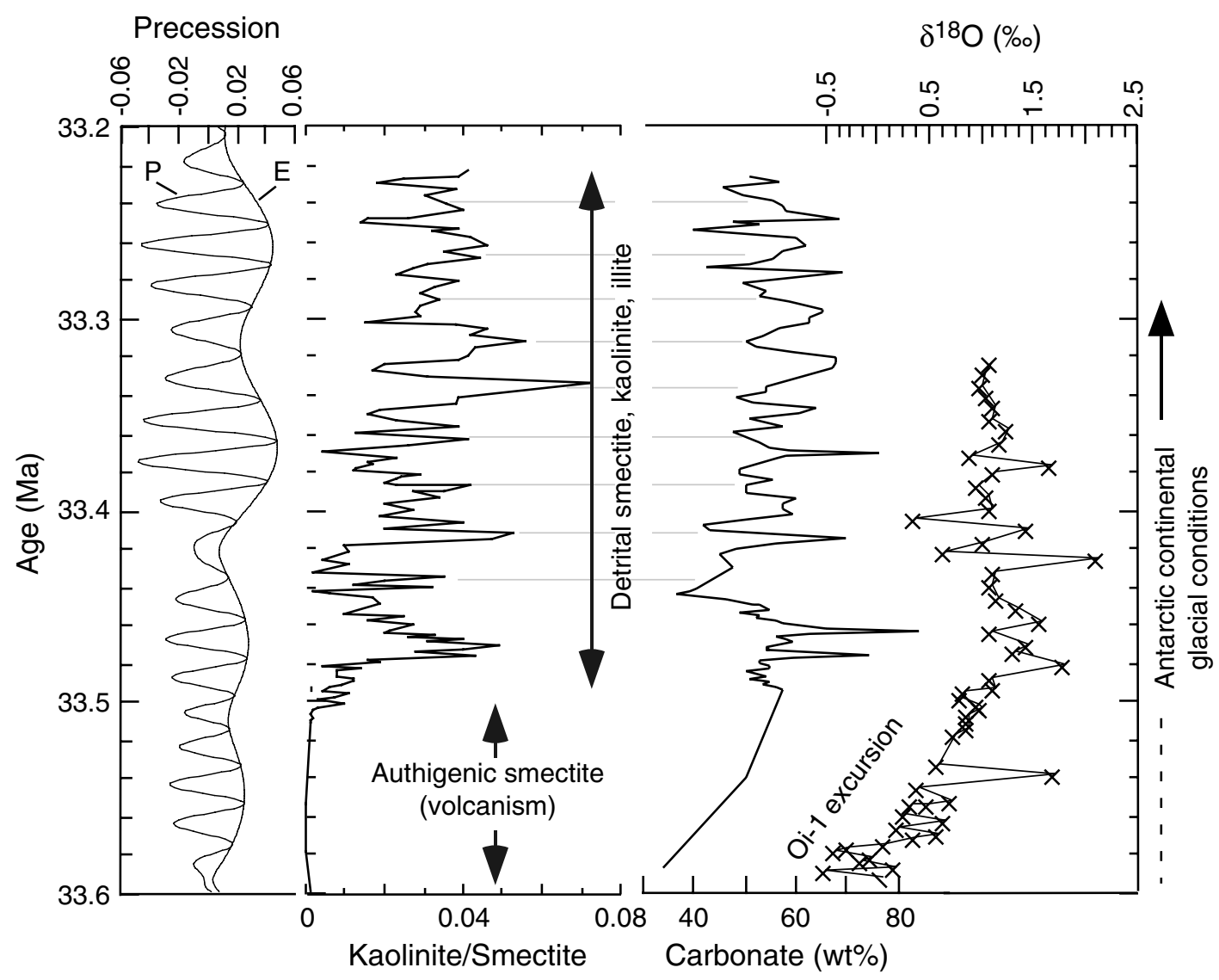

